\title{
Major palaeoenvironmental perturbation in an Early Aptian carbonate platform: Prelude of the Oceanic Anoxic Event 1a?
}

\author{
María Najarro ${ }^{\mathrm{a}, *}$, Idoia Rosales $^{\mathrm{a}}$, Javier Martín-Chivelet ${ }^{\mathrm{b}}$ \\ a Departamento de Investigación y Prospectiva Geocientífica, Instituto Geológico y Minero de España, IGME, Ríos Rosas 23 , 28003 Madiid, Spain \\ ${ }^{b}$ Departamento de Estratigrafia, Instituto de Geología Económica (CSIC-UCM), Facultad de Ciencias Geológicas. Universidad Complutense, 28040 Madrid, Spain
}

\section{Keywords:}

Carbonate platform

OAE 1a

Heterozoan facies

Meteoric diagenesis

Early Aptian

Cantabria

\begin{abstract}
A B S T R A C T
The Early Aptian Oceanic Anoxic Event (OAE 1a) was characterized by intensified greenhouse climate conditions, widespread accumulation of organic deposits in open-marine settings, major perturbations in the $\mathrm{C}$ cycle and a generalized increase in terrestrial runoff. Sedimentological, diagenetic and chemostratigraphic analyses of Lower Aptian platform carbonates from the North Cantabrian basin ( $\mathrm{N}$ Spain) illustrate the regional impact and effects of those global conditions on shallow marine environments.

The studied interval outlines four stages of platform evolution. Stage 1 (earliest Bedoulian) is defined by an initial rapid marine transgression that led to deposition of shallow water oligotrophic photozoan skeletal assemblages, and by a later interval of subaerial exposure. Stage 2 (early Bedoulian) starts with a rapid transgression followed by deposition of grainstones that yield heterozoan assemblages, more typical of mesotrophic conditions, along with ferruginized oolites. Stage 3 (early Bedoulian) is defined by the drowning of the carbonate platform and subsequent deposition of open-marine marls, which are thought to represent the local expression of the OAE $1 \mathrm{a}$. Finally, stage 4 shows the return of shallow water photozoan carbonate sedimentation. The carbonate $O$ and $C$ stable isotope records have revealed prominent negative excursions during deposition of the marly interval of the stage 3, which may be associated with the important global changes that occurred at the onset of the OAE 1a. The change in skeletal assemblages that preceded the isotopic excursions and the platform drowning documents conditions of environmental stress caused by a combination of local and global factors. The global change, coupled with increased basin subsidence, triggered the drowning of the platform by progressive reduction of the growth potential of the carbonate factory.
\end{abstract}

\section{Introduction}

The Cretaceous shallow carbonate platforms of the northern Tethys domain are typically characterized by rudist-dominated facies with corals and green algae, which are considered as an oligotrophic, photozoan style of carbonate production (e.g. Carannante et al., 1995; James, 1997; Philip and Gari, 2005; Föllmi et al., 2006; Burla et al., 2008). Their evolution is however punctuated by some stages of dominance of heterozoan communities as well as several phases of platform demise (e.g. Föllmi et al., 1994, 2006; Philip and Gari, 2005; Weissertet al., 1998). One of the best known stage of platform growth crisis occurred during the Early Aptian linked to a global oceanic anoxic event, the so-called OAE $1 \mathrm{a}$. This event was characterized by widespread distribution of organic-rich deposits, and was associated to extreme greenhouse conditions and significant changes in the

\footnotetext{
* Corresponding author. Tel.: +3491 7287288; fax: +34917287202.

E-mail addresses: m.najarro@igme.es (M. Najarro), i.rosales@igme.es (I. Rosales), j.m.chivelet@geo.ucm.es (J. Martín-Chivelet).
}

ocean-climate system (Schlanger and Jenkyns, 1976; Spicer and Corfield, 1992; Jenkyns, 2003). During this time, widespread drowning of shallow water carbonate platforms appears to have been synchronous at a global scale, defining a correlation between the OAE $1 \mathrm{a}$ and these drowning incidents (e.g. Arnaud-Vanneau and Arnaud, 1990; Hunt and Tucker, 1993; Jansa, 1993; Masse, 1993; Scott, 1993; Föllmi et al., 1994; Lehmann et al., 1998; Ruiz-Ortiz and Castro, 1998; Weissert et al., 1998; Bosellini et al., 1999; Wissler et al., 2003). One indicator of the influence upon the platform carbonates of environmental change associated to this event is the occurrence of significant variations in styles of carbonate production and diagenesis. In fact, the anoxic event is not other than the effect of a battery of interrelated palaeoclimatic and palaeoceanographic changes that converge at this time and whose triggering mechanisms are still poorly understood. Under such situation of environmental collapse, carbonate sedimentation is expected to suffer strong modifications. One important consequence is that heterozoan associations become dominant in the platforms (Simone and Carannante, 1988; James, 1997). However, there are still few references to heterozoan style of carbonate production during this 
period, and a timing correspondence between rising of heterozoan facies and the anoxic episode has not yet been clearly established.

This study examines the effects of the OAE $1 \mathrm{a}$ on the style of carbonate sedimentation and early diagenesis of a Lower Aptian carbonate platform from northwest Cantabria, in northern Spain. The area exhibits a well-exposed and continuous succession of Aptian shallow water platform carbonates that include a Lower Aptian openmarine marly unit (Patrocinio Formation). The latter is thought to represent a short-lived episode of platform drowning and the local expression of the OAE 1a (Wilmsen, 2005; Najarro and Rosales, $2008 a, b)$. The carbonate platform turned from photozoan to heterozoan biogenic assemblages before experiencing platform drowning. In attempts to explain the change of carbonate production and the drowning event, several questions arise: (I) which factors determined the carbonate factory shutdown and the drowning of the Cantabrian platform?, (II) to which extent all those changes could be induced or enhanced by regional mechanisms (e.g., local tectonics) rather than global forcings? Sedimentological, geochemical, and diagenetic data are evaluated here in order to address those questions and to discriminate the effects of the OAE $1 \mathrm{a}$ on shallow carbonate deposition.

\section{Geological setting}

The studied area is located in the northwestern margin of the Basque-Cantabrian Basin (BCB; Fig. 1). During the Cretaceous, this part of the $B C B$ belonged to the northern margin of the Iberian plate and was subjected to extension. The $\mathrm{BCB}$ evolution and its current structure are the result of a complex kinematics between the European and Iberian plates (Malod and Mauffret, 1990; Olivet, 1996). After a first extensional phase during the Permian-Triassic, a second rifting phase linked to the opening of the Bay of Biscay and North Atlantic ocean took place during the Late Jurassic-Early Cretaceous (e.g. Le Pichon and Sibuet, 1971; Rat, 1988; García-Mondéjar et al, 1996; Martín-Chivelet et al, 2002). Renewed extension and perhaps left-lateral strike slip movement along NW-SE faults occurred in the Aptian-Cenomanian, during the last rifting phases (e.g. Malod and Mauffret, 1990; Garcia-Mondé jar et al., 1996; Soto et al., 2007). Due to these tectonic events, numerous extensional basins and sub-basins bounded by active synsedimentary faults developed in the North Iberian plate margin (Fig. 1A).

The studied succession was deposited in one of these sub-basins, the North Cantabrian basin (NCB; Fig. 1B). This area developed as a

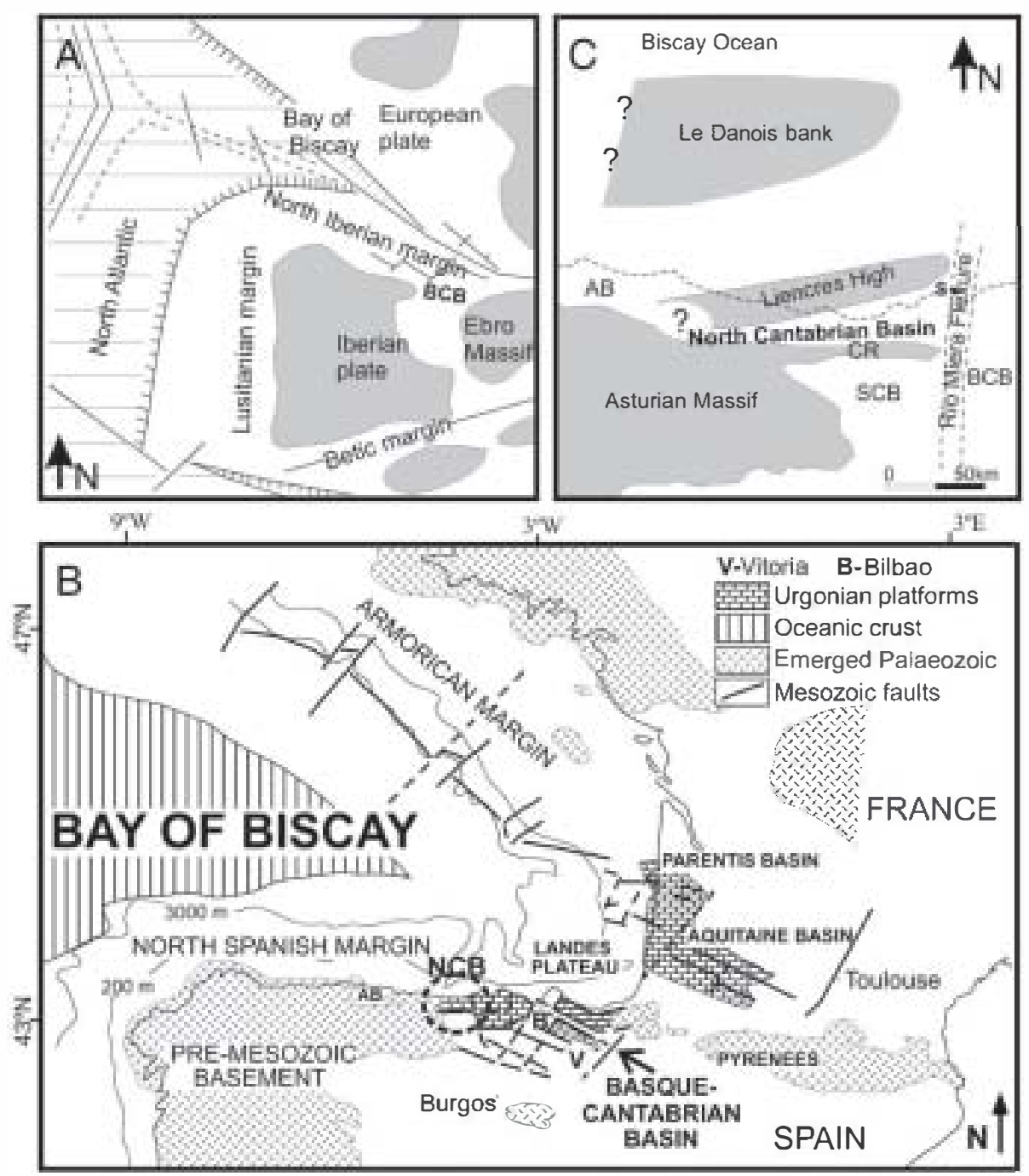

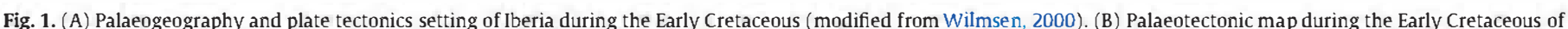

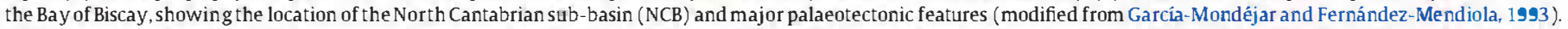

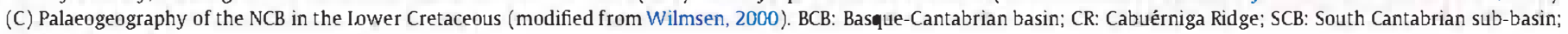
$\mathrm{AB}$ : Asturian basin. 
relatively small $(\sim 20 \times 80 \mathrm{~km})$, E-W elongated sub-basin, that behaved independently for most of the Cretaceous time (Fig. 1C). The NCB was separated from the more strongly subsiding rest of the $\mathrm{BCB}$ to the east, by a N-S extensional structure (Río Miera Flexure; Feuillee and Rat, 1971) (Fig. 1C). To the south it was limited by the Cabuérniga Ridge (Figs. $1 \mathrm{C}$ and 2), an E-W trending palaeo-high which represents a previous $\mathbf{V}$ ariscan tectonic structure reactivated as extensional faults during the Mesozoic (Rat, 1988; García-Espina, 1997). To the west, the NCB was bounded by the Asturian Massif and, to the north, by the Iiencres High, an ENE-WSW trending swell now situated mostly offshore in the Bay of Biscay (Wilmsen, 2000) (Fig. 1C). Internally, the NCB was configured into swells and troughs controlled by the presence of $\mathrm{N}-\mathrm{S}$ and $\mathrm{E}-\mathrm{W}$ oriented synsedimentary faults and secondarily by NE-SW oriented faults (Najarro et al., 2009). Among the principal synsedimentary faults, it is worth mentioning the important role that played the North Cabuérniga and Bustriguado faults (Fig. 2A), which controlled subsidence patterns during the Early Cretaceous and determined strong local changes in sedimentary accumulation (Fig. 2B) (Najarro et al., 2007, 2009). As shown in the SW-NE cross-section of Fig. 2, the NCB can be divided into three main
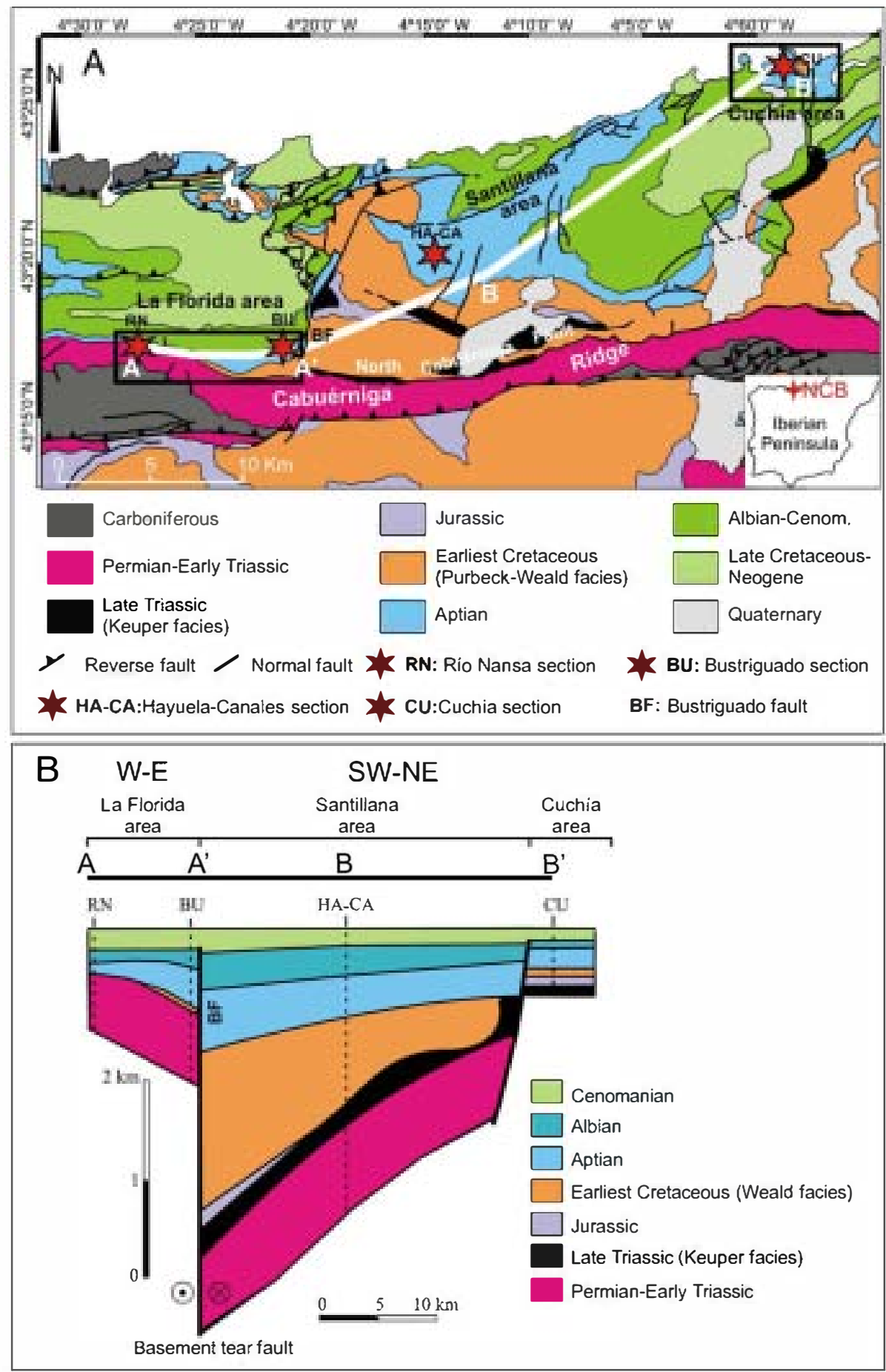

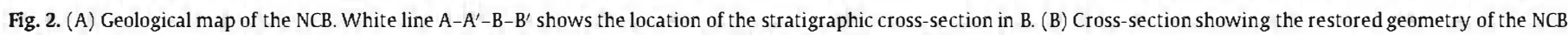
during the Cretaceous and the sedimentary record in the three principal areas (La Florida, Santillana and Cuchia). 
areas according to their tectonic evolution and stratigraphy, from SW to NE: La Florida, Santillana, and Cuchía. The areas of La Florida and Cuchía represent respectively two low-subsiding blocks. Between them, the Santillana area formed a sedimentary trough and the main depocentre of the NCB during the Early Cretaceous (Fig. 2).

\section{Stratigraphy}

The general stratigraphic and biostratigraphic frameworks of the Aptian successions of the NCB were established by Ramirez del Pozo (1972), Collignon et al. (1979) and Hines (1985). More recently, the main depositional systems and sequences have been revised, establishing a new lithostratigraphic unit (Rábago Formation) and updating the stratigraphic and biostratigraphic schemes (Figs. 3 and 4) (Najarro and Rosales, 2008c; Najarro et al., 2009; Rosales et al., 2009). The Aptian lithostratigraphy of the NCB is composed of six formations, named from oldest to youngest (Fig. 3): 1) Rábago Formation (early Bedoulian, Palorbitolina lenticularis zone), which consists of shallow platform sandstones, orbitolinid marls and rudists limestones. 2) Umbrera Formation (early Bedoulian, P. lenticularis zone), composed of shallow platform cross-bedded grainstones. 3) Patrocinio Formation (mostly early Bedoulian, Deshayesites weissi ammonite zone and middle upper part of the Hayesites irregularis nannofossil zone; Rosales et al., 2009), made of open-marine marls. 4) San Esteban Formation (late Bedoulian), characterized by shallow platform rudist-bearing limestones, with Iraquia simplex (Pascal, 1985).5) Rodezas Formation (latest Bedoulianearly Gargasian, according to Collignon et al., 1979), made of shallow marine sandstones, marly limestones and marls; and finally 6) Reocin Formation (Gargasian-Clansayesian, Orbitolina (Mesorbitolina) texana texana and Simplorbitolina manasi zones; Ramírez del Pozo, 1972), composed of shallow water coral and rudist-bearing limestones.

In the La Florida area, the Aptian succession consists of an E-W elongate lithosome, $9 \mathrm{~km}$ long, with wedge-shaped geometry deepening and thickening eastward, on the slope of a tilted block active during this time (Najarro et al., 2007) (Fig. 2B). In this area, the initial
Early Aptian marine transgression led to deposition of the Rábago and Umbrera formations (Figs. 3 and 4). Continued transgression during the early Bedoulian caused platform drowning and resulted in deposition of the Patrocinio Formation, which completely covered the former carbonate platform. Subsequent regression during the Late Aptian originated the deposition of the Reocin Formation (Figs. 3 and 4). New biostratigraphic data based on calcareous nannofossils (Rosales et al., 2009) reveal the existence of a stratigraphic gap (paraconformity) in this area that comprises at least the late Early Aptian (late Bedoulian). This stratigraphic gap is time-equivalent to the San Esteban Formation, which is missed in this area (Fig. 4). In contrast, in the Santillana area the Aptian succession is essentially complete without major hiatuses and the lithological units show their largest thicknesses (Fig. 3).

Finally, in the Cuchía area, the first recorded Aptian unit is the Umbrera Formation, which rests unconformably on continental Wealdean facies (Fig. 3). Remarkably, the Rábago unit is missing here (Figs. 3 and 4), probably because it was eroded before the deposition of Umbrera Formation, or alternatively because it pinched out in this area. Subsequent transgression produced deposition of the marly Patrocinio Formation. The upper part of this unit shows in this area an upward increase in the content of siliciclastic siltstones and sandstones which resulted of a local delta progradation (Wilmsen, 2005). The siliciclastic deltaic deposits grade upwards to the San Esteban Formation. Like in the previous area, the Late Aptian stratigraphy is represented by the Rodezas and Reocin Formations, except in the Suances section where these two units are absent; indicative of a depositional and/or erosive hiatus that comprises at least the entire Late Aptian (Fig. 3).

\section{Methodology and studied sections}

A total of eight laterally correlative stratigraphic sections were measured and analyzed through the NCB for this work (Fig. 5). Six of them belong to the La Florida area (from W to E: Río Nansa, Rábago,

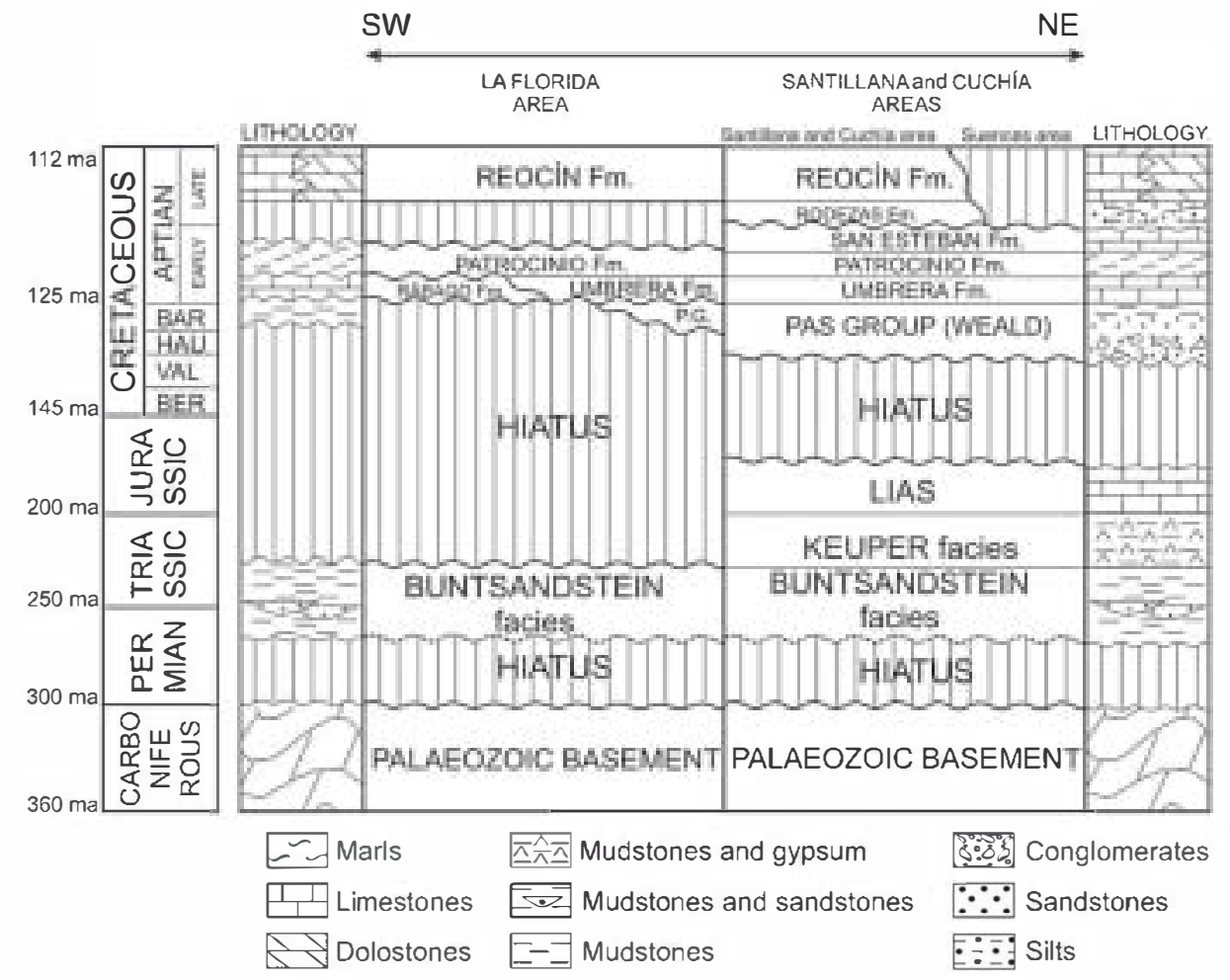

Fig. 3. Lithostratigraphy of the La Florida, Santillana and Cuchía areas. P.G. is Pass Group (Weald). Chronostratigraphy after Gradstein (2004). 


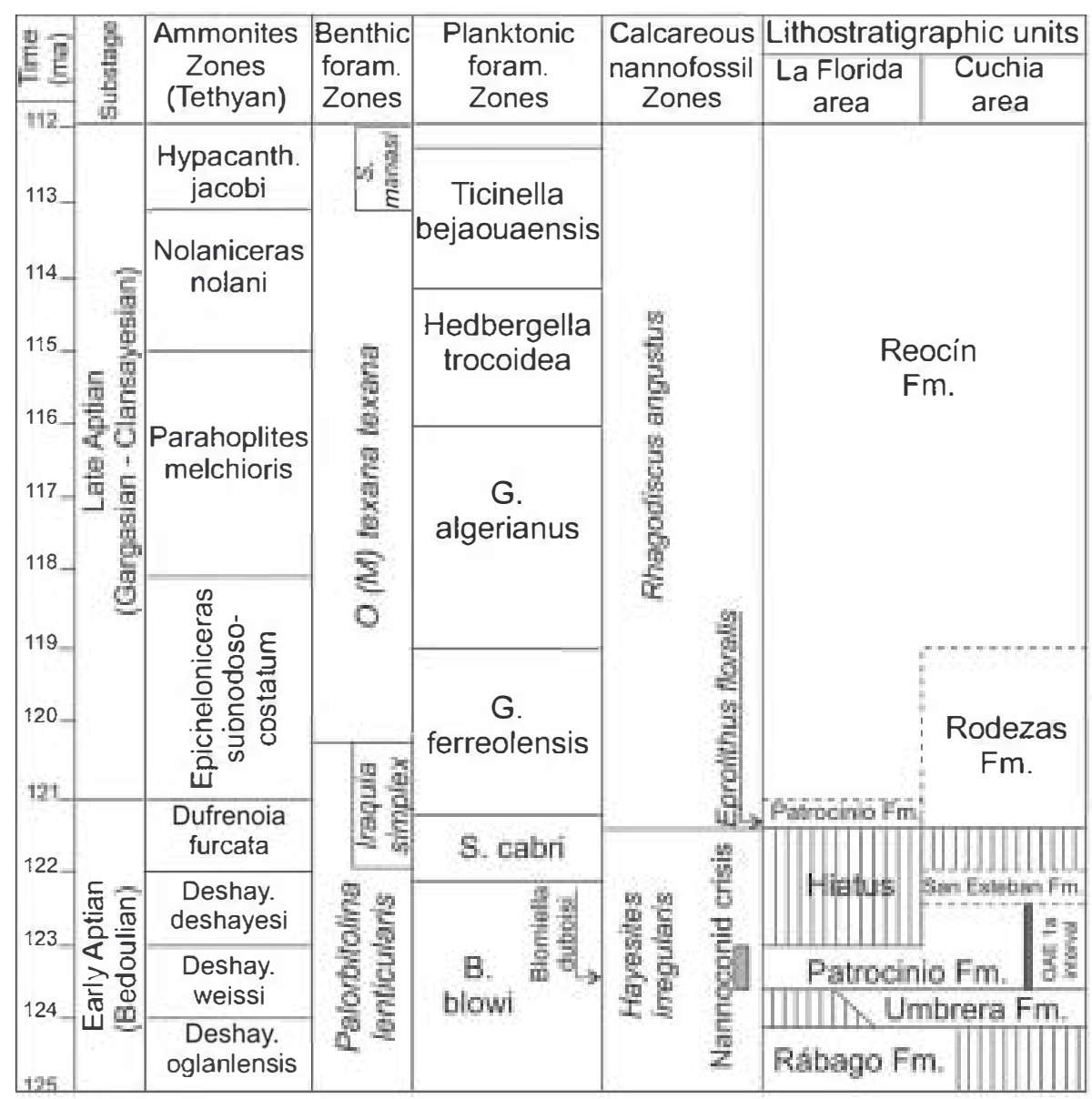

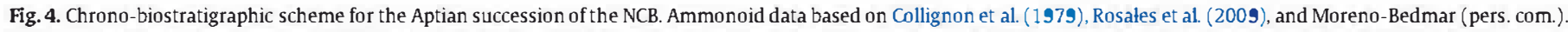

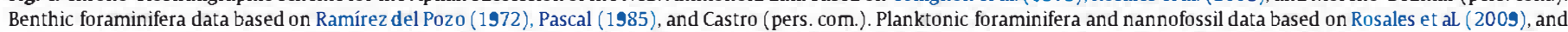
de Gea (pers. com.). The OAE 1a interval is equivalent to the "Selli level" defined by Menegatti et al. (1998). Chronostratigraphy after Gradstein (2004).

El Soplao, La Florida, Corona de Arnero, and Bustriguado, Fig. 6). The other two are considered to be representative of the Santillana and Cuchía areas respectively: the first one logged between the villages of Hayuela and Canales, and the second at the Los Caballos beach near the village of Cuchía (Fig. 2A).

When outcrop conditions were favourable, sedimentological features and macrofossil content were documented in detail in the field and sampling for microfaciesanalysis was conducted systematically (at least 1 sample per $2 \mathrm{~m}$, often at a smaller scale). Uncovered and polished thin sections were investigated with an optical microscope and cold cathodoluminescence (CL), and then classified according to microfabrics and mineral composition. Thin sections were stained with a mixture of Alizarin Red S and potassium ferricyanide (Dickson, 1966) to aid in the identification of ferroan and non-ferroan phases of calcite and dolomite. Cathodoluminescence (CL) analyses were obtained from a Technosyn cold cathodoluminescence operator model CL8200 MK5, operating at $\sim 15 \mathrm{kV}$ with a current of 500-600 $\mu \mathrm{A}$. Oxygen and carbon stable isotope analyses were performed on limestone and marl samples throughout two selected stratigraphic sections (Río Nansa and Rábago), which may be easily correlated and combined to conform a composite complete section. Powders for isotope analyses were retrieved by using a microdrill on micrites and marls, and avoiding diagenetic calcite and dolomite from crack fillings, replaced fossils or matrix irregularities, especially in limestone samples. The sample material was treated with $100 \%$ orthophosphoric acid using the conventional digestion method (McCrea, 1950) and the $\varepsilon^{13} \mathrm{C}$ and $\delta^{18} \mathrm{O}$ composition of the evolving $\mathrm{CO}_{2}$ gas was analyzed in a SIRA-II doted with an "ISOCARB" automatic system at the University of Salamanca (Spain). The results are expressed in the common $\delta$-notation in per mil (\%) relative to VPDB-standard. The international carbonate standard NBS-19 (National Bureau of Standards; $\varepsilon^{13} \mathrm{C}=1.95 \%$ and $\varepsilon^{18} \mathrm{O}=-2.20 \%$ ) was used to calibrate the $\mathrm{PDB}$, with an average precision of $0.01 \%$ for $\delta^{13} \mathrm{C}$ and $0.05 \%$ for $\delta^{18} \mathrm{O}$.

\section{Stages of platform evolution}

During the Early Aptian, the shallow water carbonate succession of the NCB presents four distinctive stages of platform evolution, which have been differentiated on the basis of facies and stratal patterns, with special emphasis in vertical changes in facies, skeletal composition and particle associations, and correlation of particular sedimentary surfaces (Figs. 5 and 6). Lithological description and interpretation of the four stages are summarized in Table 1, which show the following principal aspects from base to top:

\subsection{Stage 1: Initial transgression and carbonate platform development}

\subsubsection{Description}

It corresponds to the Rábago Formation. In the studied sections it presents a maximum thickness of 12-17 $\mathrm{m}$. Its basal part is predominantly siliciclastic or mixed carbonate-siliciclastic, whereas the upper part is mostly carbonate altemating with some orbitolinid-rich marls (Fig. 7). Vertical stacking patterns of facies show three main facies associations, which from base to top are: i) siliciclastic platform, ii) mixed carbonatesiliciclastic platform, and iii) carbonate platform (Fig. 7 and Table 1).

Siliciclastic platform facies are present at the base of Río Nansa and Rábago sections (Fig. 7). They consist of a 5 to $7 \mathrm{~m}$ thick interval of 


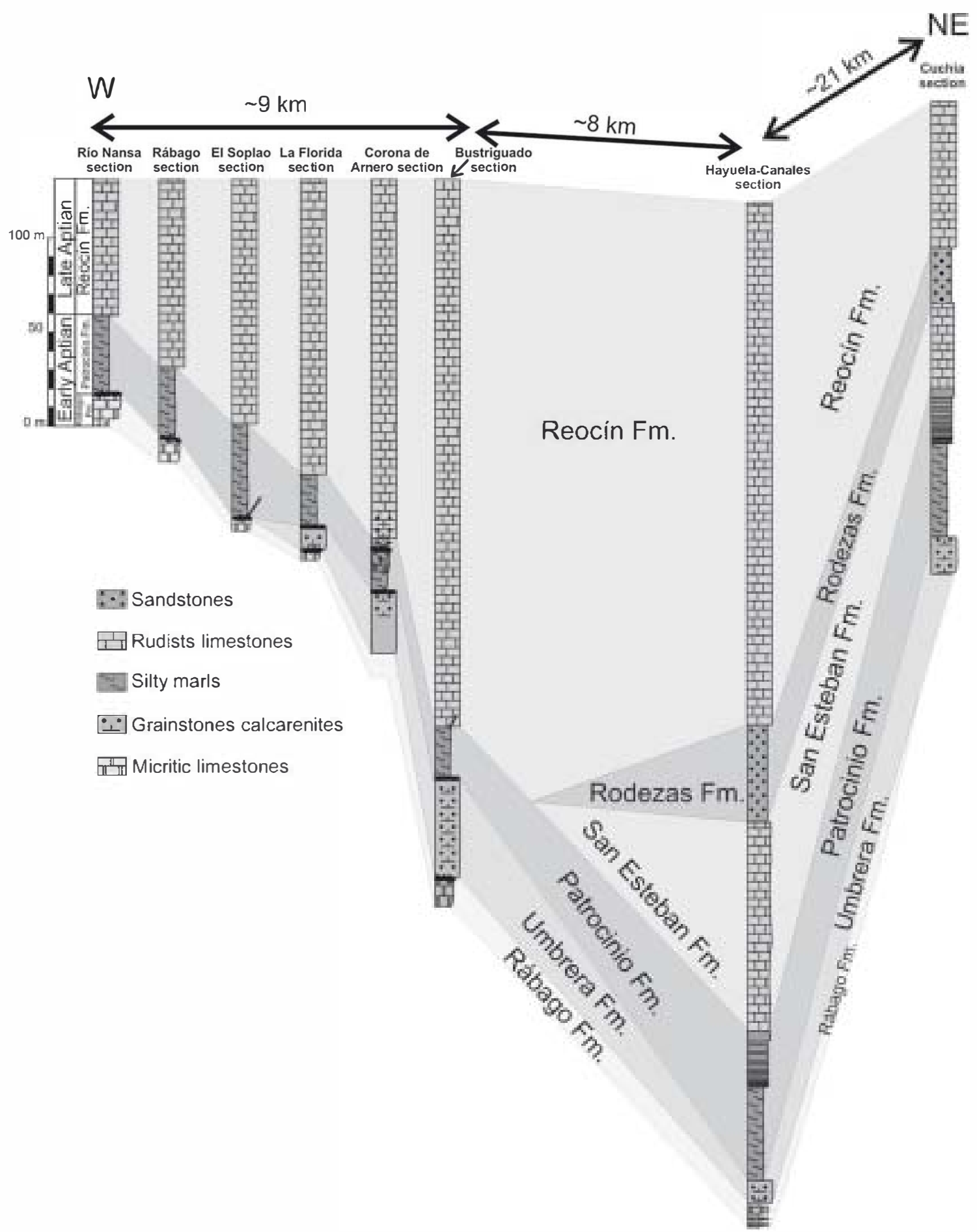

Fig. 5. Lithostratigraphic correlation of logged sections through the NCB, showing the main units, depositional facies and lateral thickess variation.

interbedded, carbonaceous and laminated claystones, siltstones and fineto medium-grained micaceous sandstones, typically with lenticular and flaser bedding, and current ripples at the tops of the sandstones beds.

Mixed carbonate-siliciclastic platform facies mainly consist of sandy limestones with variable amount of quartz sand and other terrigenous grains. They are organized in tabular beds $20 \mathrm{~cm}$ to $1 \mathrm{~m}$ thick (Fig. 8A), which often show wavy lamination and occasionally wave ripples at the bed tops. These sandy limestones are interbedded with claystonessiltstones, packstone-grainstones, and orbitolinid-rich marls (Fig. 7).

Carbonate platform facies consist of alternations of orbitolinid-rich marls and nodular marly limestones, grainstones, packstones, wackestones and mudstones with corals and rudists of small size (Figs. 7 and 8B). They are organized in planar to nodular, massive beds ranging from 0.3 to $1 \mathrm{~m}$ thick. These facies are arranged in a finingupward succession. Hence, packstone and grainstone are the most frequent textures in the lower terms of the succession, whereas coralrudist wackestone and microbialite mudstone with fenestral fabrics developed on the upper part (Fig. 7 and Table 1).

In the La Florida area, the succession culminates with a dissolution surface displaying irregular cavities of decimetre size, fissures and macro and micro topographic relief with corrosive surfaces and indents. Interestingly, a thin Fe-rich crust appears in places coating the 
Table 1

Main characteristics of the different stages of the carbonate platform.

\begin{tabular}{|c|c|c|c|c|c|c|c|}
\hline \multicolumn{2}{|l|}{ Characteristics } & \multicolumn{2}{|l|}{ Stage 1} & \multirow{2}{*}{$\begin{array}{l}\text { Stage } 2 \\
\text { Grainstones and } \\
\text { packstones, rarely } \\
\text { rudstones. Orbitolinid } \\
\text { marls upsection }\end{array}$} & \multicolumn{2}{|c|}{ Stage 3} & \multirow{2}{*}{$\begin{array}{l}\text { Stage } 4 \\
\text { Wackestones, } \\
\text { packstones and } \\
\text { many limestones }\end{array}$} \\
\hline Lithology & $\begin{array}{l}\text { Interbedded, } \\
\text { carbonaceous and } \\
\text { laminated claystones, } \\
\text { siltstones and } \\
\text { micaceous sandstones }\end{array}$ & $\begin{array}{l}\text { Sandy limestone } \\
\text { with quartz sand }\end{array}$ & $\begin{array}{l}\text { Marls, marly limestones, } \\
\text { grainstones, packstones, } \\
\text { wackestones, and } \\
\text { mudstones }\end{array}$ & & $\begin{array}{l}\text { Silty marls to } \\
\text { dark-grey, } \\
\text { soft clayed } \\
\text { marls }\end{array}$ & $\begin{array}{l}\text { Siltstones and } \\
\text { mica-rich } \\
\text { sandstones }\end{array}$ & \\
\hline $\begin{array}{l}\text { Primary } \\
\text { structures, } \\
\text { vertical stacking } \\
\text { and bioturbation }\end{array}$ & $\begin{array}{l}\text { Lenticular and flaser } \\
\text { bedding; current } \\
\text { ripples }\end{array}$ & $\begin{array}{l}\text { Wary } \\
\text { lamination; } \\
\text { current ripples }\end{array}$ & $\begin{array}{l}\text { Planar to nodular massive } \\
\text { beds. Fining-upward }\end{array}$ & $\begin{array}{l}\text { High-amplitude wavy } \\
\text { lamination; planar- } \\
\text { oblique and high-angle } \\
\text { cross-stratification; } \\
\text { internal erosive surfaces, } \\
\text { bi-directional and } \\
\text { sigmoidal cross- } \\
\text { stratification. Thinning- } \\
\text { and fining-upward. } \\
\text { Thalassinoides up section. }\end{array}$ & - & $\begin{array}{l}\text { Ripple trough } \\
\text { cross-bedding } \\
\text { flaser and } \\
\text { lenticular } \\
\text { bedding. } \\
\text { Coarsening- } \\
\text { upward and } \\
\text { ophiomorph } \\
\text { nodos }\end{array}$ & Fining-upward \\
\hline $\begin{array}{l}\text { Particle } \\
\text { composition }\end{array}$ & $\begin{array}{l}\text { Wood fragments, } \\
\text { fine- to medium- } \\
\text { grained quartz, clay } \\
\text { minerals and mica }\end{array}$ & $\begin{array}{l}\text { Orbitolinids, } \\
\text { echinoderm } \\
\text { plates and thin } \\
\text { shelled bivalves. } \\
\text { Clay minerals } \\
(5 \%)\end{array}$ & $\begin{array}{l}\text { Protozoan: Rudist and } \\
\text { coral lithosomes, } \\
\text { L. aggregatum-B. } \\
\text { irregularis, miliolids, } \\
\text { nerineid gastropods, } \\
\text { Chondrodonta, } \\
\text { dasycladacean green algae, } \\
\text { orbitolinids, peloids, } \\
\text { intraclasts and micritized } \\
\text { grains }\end{array}$ & $\begin{array}{l}\text { Heterozoan: Iarge } \\
\text { agglutinated benthic } \\
\text { foraminifera, bryozoans, } \\
\text { plates and spines, of } \\
\text { echinoderms, crinoid } \\
\text { ossicles, red algae, oysters, } \\
\text { bivalves, gastropods, } \\
\text { quartz grains, glauconite, } \\
\text { calcite ooids, ferruginized } \\
\text { ooids and coated grains, } \\
\text { extraclasts, and plant } \\
\text { fragments }\end{array}$ & $\begin{array}{l}\text { Ammonites, } \\
\text { belemnites, } \\
\text { planktonic } \\
\text { foraminifera } \\
\text { nannofossils, } \\
\text { glauconite, } \\
\text { and Fe- } \\
\text { nodules }\end{array}$ & $\begin{array}{l}\text { Bivalves, } \\
\text { brachiopods, } \\
\text { echinoids, } \\
\text { orbitolinids, } \\
\text { and wood } \\
\text { fragments }\end{array}$ & $\begin{array}{l}\text { Protozoan: Rudists } \\
\text { and corals } \\
\text { lithosomes, } \\
\text { miliolids, } \\
\text { orbitolinids, } \\
\text { calcareous algae, } \\
\text { L. aggregatum-B. } \\
\text { irregularis, peloids, } \\
\text { and bioclasts }\end{array}$ \\
\hline $\begin{array}{l}\text { Depositional } \\
\text { environment }\end{array}$ & Siliciclastic platform & $\begin{array}{l}\text { Mixed } \\
\text { carbonate- } \\
\text { siliciclastic } \\
\text { platform }\end{array}$ & $\begin{array}{l}\text { Restricted inner carbonate } \\
\text { platform. Low energy and } \\
\text { shallow water conditions. } \\
\text { Shallowing upward and } \\
\text { emersion at the top }\end{array}$ & $\begin{array}{l}\text { Inner to mid carbonate } \\
\text { shelf. High-energy shallow } \\
\text { bars and shoals }\end{array}$ & Open marine & $\begin{array}{l}\text { Delta } \\
\text { progradation }\end{array}$ & $\begin{array}{l}\text { Restricted inner } \\
\text { carbonate platform. } \\
\text { Low energy and } \\
\text { shallow water } \\
\text { conditions }\end{array}$ \\
\hline Nutrient levels & - & + & Oligotrophic & Meso-eutrophic & - & - & Oligotrophic \\
\hline Cement C1 & - & - & Scarce & High & - & - & Scarce \\
\hline Cement C2 & $n$ & $=$ & High & Only in reworked bioclasts & $=$ & $=$ & $=$ \\
\hline Glauconite & - & - & - & High & High & - & - \\
\hline Ferruginization & - & + & 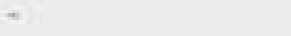 & High & - & - & + \\
\hline$\delta^{13} \mathrm{C}$ values & - & - & $\begin{array}{l}\text { Stable and positive } \\
\text { values. Mean: } 2.2 \%\end{array}$ & $\begin{array}{l}\text { Progressive decrease } \\
\text { of } \sim 1 \% \text {. Positive } \\
\text { values. Mean: } 1.1 \% \text {. }\end{array}$ & $\begin{array}{l}\text { Negative excur } \\
-0.41 \% \text { to }-4\end{array}$ & $\begin{array}{l}\text { sion from } \\
.53 \%\end{array}$ & $\begin{array}{l}\text { Positive excursion. } \\
\text { Mean } 2.8 \%\end{array}$ \\
\hline
\end{tabular}

coated by the Fe-rich crust. The end of the carbonate stage 2 is marked by a discontinuity on top of a bioturbated and reddish calcarenite bed, which is covered by marls of the Patrocinio Formation (Fig. 10A).

\subsubsection{Inter pretation}

Sedimentary lithofacies and structures suggest that high-energy tidal and coastal currents controlled deposition of these carbonate sands (sand waves). They represent high-energy shallow bars and shoals deposited in an open-marine, inner to midcarbonate shelf environment. At the upper part of the succession, abandoned bars were rapidly colonized by burrowing organisms (Thalassinoides) and then buried by marls. This suggests an overall deepening trend of the succession linked to a transgressive episode.

\subsection{Stage 3: Carbonate platform drowning at the onset of OAE 1a}

\subsubsection{Description}

The stage is represented by the Patrocinio Formation (Fig. 10A). Open-marine marls of this unit abruptly overlie the shallow water carbonates of stage 2 . Lithofacies are formed by silty marls to darkgrey, soft clayed marls with glauconite and ironstone nodules. These yield ammonites, belemnites, and microfossils including planktonic foraminifera and nannoplankton. Up-section, the silt content of the marls increases and appear bioclastic beds with erosional surfaces, and debris of bivalves, brachiopods, echinoids and orbitolinids as well as wood fragments. Bioturbation also becomes intense upwards. In the Cuchia area (Fig. 10A), the upper part of the stage 3 records an upward increase in the content of siltstones and mica-rich, bioturbated sandstones with Ophiomorpha nodosa, ripple trough crossbedded sandstones, and heterolithic facies with flaser and lenticular bedding, organized in a thickening and coarsening-upward sequence.

\subsubsection{Interpretation}

These deposits reflect the shutdown of the shallow water carbonate factory in the area and the drowning of carbonate platform stage 2, likely as the result of a combined action of a relative sea-level rise and poisoning by siliciclastic particles. The lower marly interval is interpreted as formed by fall of fine carbonate particles mixed with fine-grained terrigenous material, under low-energy conditions below storm wave base. Up-section, the increment of silt content suggests input of coarser siliciclastic material from continent. The bioclastic erosive layers suggest storm beds deposited above the storm wave base, and finally, the sandstone lithofacies at the top represents progradation of deltaic facies (Wilmsen, 2005). This whole succession indicates a net shallowing-upward trend and rapid regression towards the end of the stage. 


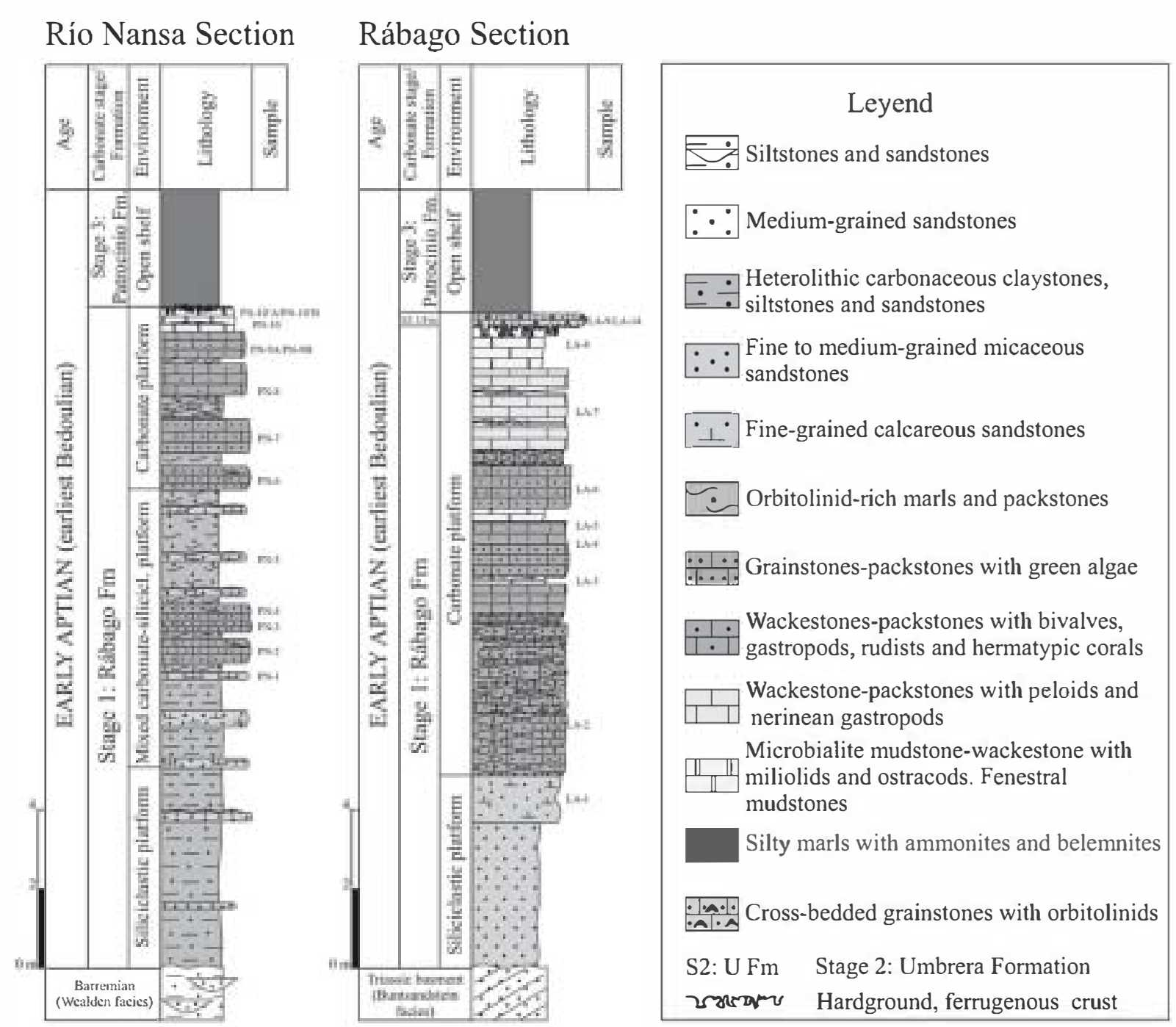

Fig. 7. Stratigraphic sections of stage 1 (Rábago Formation) at Río Nansa and Rábago localities, showing the main depositional environments and facies associations.

\subsection{Stage 4: Carbonate platform recovering}

\subsubsection{Description}

The shallow water carbonate production and deposition recovered during the late Early Aptian (late Bedoulian) and dominated until the Late Aptian. The interval is represented by decimetre- to metre-scale beds of wackestones and packstones with rudist-coral assemblages and $L$. aggregatum-B. irregularis oncoids. The succession starts with up to $4 \mathrm{~m}$ of orbitolinid-rich, marly to nodular limestone beds (Fig. 10BD), that are usually followed by marly limestones with orbitolinids, bioclasts, sponges and corals; these grading upward to well-bedded limestones with abundant requieniid rudists (Toucasia and Requienia) (Fig. 10C).

\subsubsection{Interpretation}

The instauration of stage 4 indicates the recovery in the effectiveness of the carbonate factory, favoured by the progressive shallowing of the depositional system and by the decontamination of terrigenous particles. When the carbonate sedimentation was reestablished, the orbitolinids were the first colonizers, due to their higher tolerance to adverse conditions such as water turbidity, terrigenous poisoning and limited light (as described in a similar case by Vilas et al., 1995). The vertical evolution from marly orbitolinid facies to micrite rudist facies may indicate a gradual environmental change to more favourable ecological conditions for carbonate secretion and biodiversity. The micritic limestones with miliolids, rudists and benthic foraminifera indicate a shallow water, restricted lagoonal environment with low terrigenous influence.

\section{Particle composition}

\subsection{Skeletal carbonate components of stages 1 and 4}

Carbonate platform lithofacies of stages 1 and 4 display comparable assemblages of skeletal components. In grainstone and packstone lithofacies, well-rounded fragments of green algae (dasycladacean, codiacean), coralline sponges, lumps of cyanobacteria, benthic arenaceous foraminifera, orbitolinids, and fragments of rudists and other bivalves are the most common carbonate components, with a minor contribution of plates and spines of echinoderms, gastropods, and fragments of branching corals, brachiopods and oysters. Microfacies of wackestone beds are dominated by intact and fragmented skeletons of rudists (mostly requieniids and monopleurids), nerineid gastropods, branching and colonial corals, dasycladacean green algae and thin shelled bivalves, with variable contributions of $L$ aggregatum$B$. irregularis oncoids, Chondrodonta, miliolids, orbitolinids and benthic agglutinated foraminifera (Fig. 11A-C). In minor proportion, coralline algae, brachiopods, echinoderm plates, oysters and ostracods are also found. 

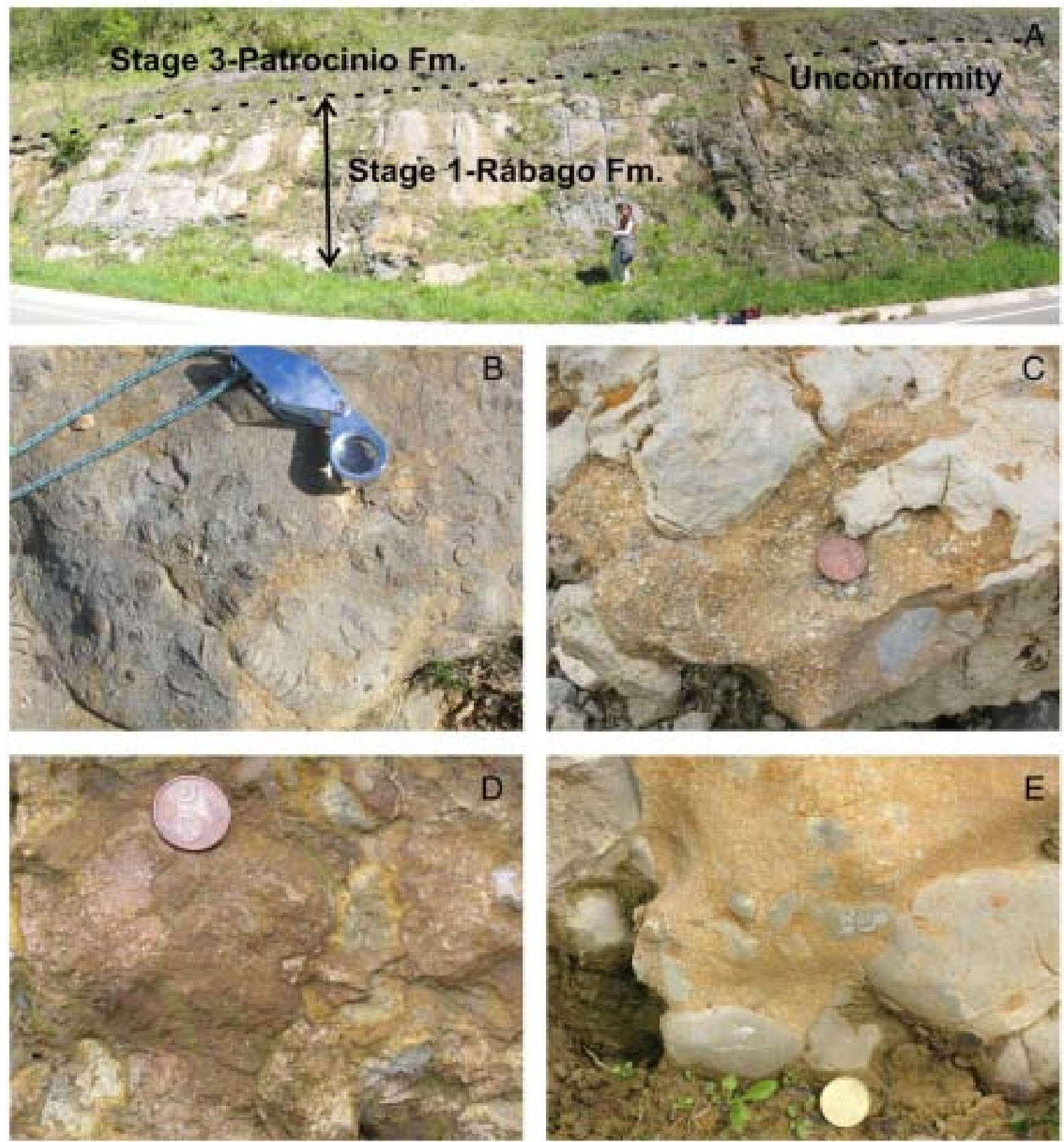

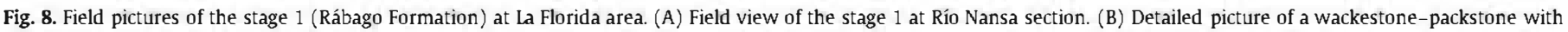

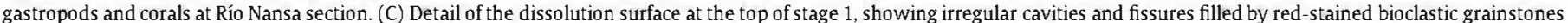

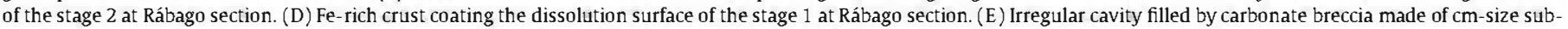
angular clasts and a matrix of red-stained bioclastic calcarenite from the stage 2 at Rábago section.

\subsection{Non-skeletal components of stages 1 and 4}

Intraclasts, peloids and micritized grains represent the most common non-skeletal particles in the carbonate platform lithofacies of stages 1 and 4 . Intraclasts $(<5 \%)$ are small and well rounded, and derived from facies of micrite matrix with foraminifera and bioclasts (Fig. 11D). Peloids are small in size, subspherical to ovoidal in shape, conspicuously rounded, and well sorted. They don't exhibit any evident structure or organization such as gradation or lamination. Silt-size grains of quartz $(<1 \%)$ and opaque minerals are also present.

\subsection{Skeletal carbonate components of stage 2}

During the carbonate stage 2, the principal skeletal components of the microfacies are large agglutinated benthic foraminifera (orbitolinids and large lituolids), bryozoans, plates and spines of echinoderms, crinoid ossicles, red algae and mollusc debris (bivalves, gastropods, and oysters) (Fig. 12A). No intact rudist shells, corals and green algae have been observed. These appear as minor components preferentially concentrated in the basal beds of the calcarenite interval, immediately above the basal unconformity, and correspond to well-rounded to subrounded, abraded fragments, generally about $1 \mathrm{~mm}$ in size or less 

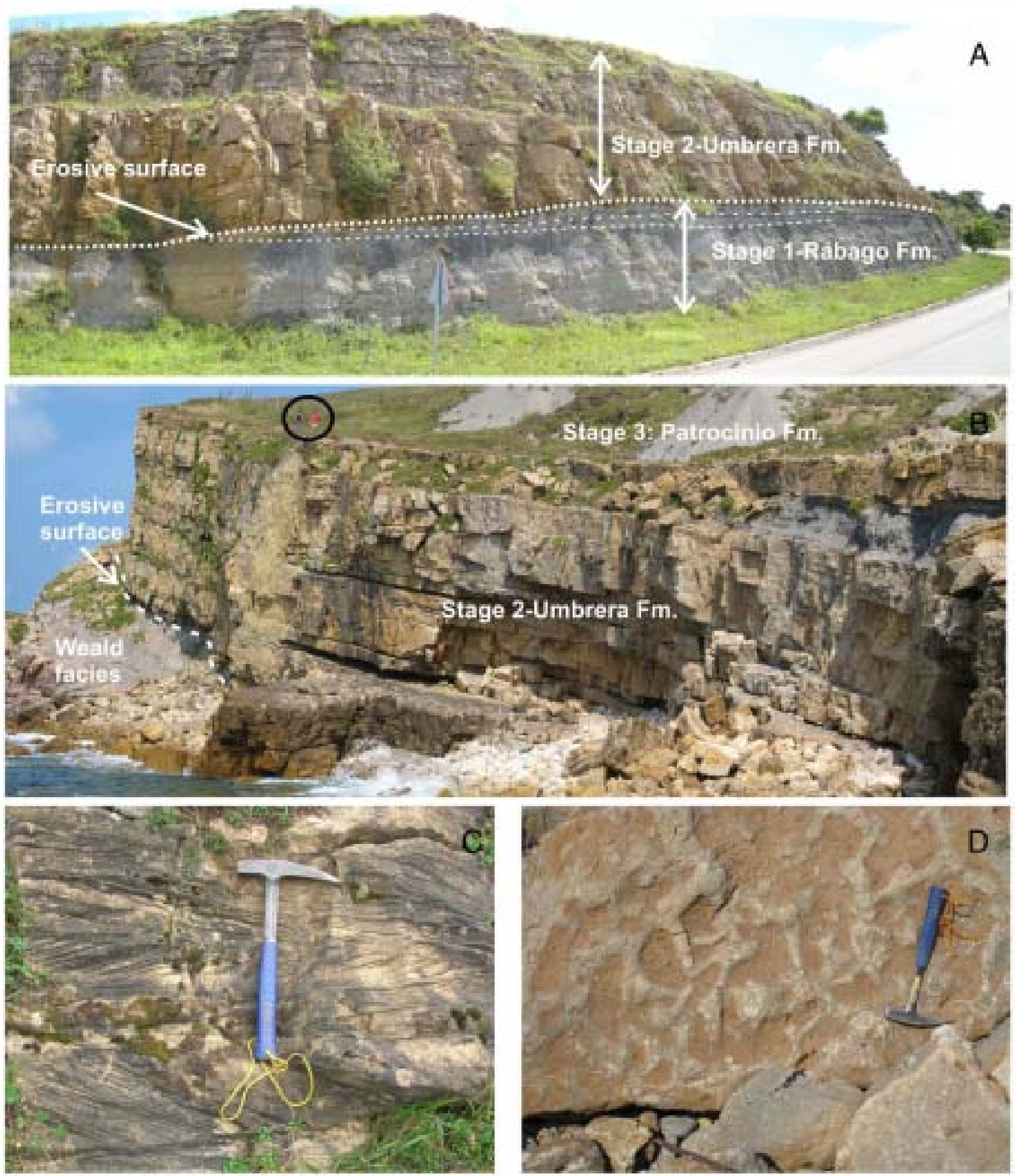

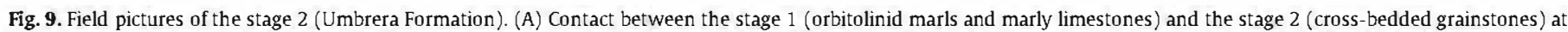

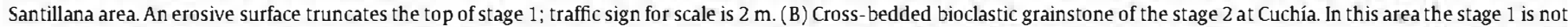

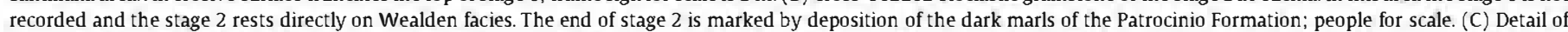

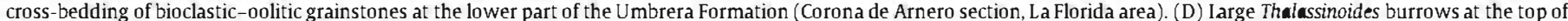
the Umbrera Formation in the Cuchía area.

(Fig. 12B). These reworked fragments of rudists and corals are recrystallized and commonly constitute the nucleus of ooids (Fig. 12C). Occasionally miliolids are present and may appear broken as well (Fig. 12B).

\subsection{Non-skeletal components of stage 2}

Non-skeletal components of stage 2 are represented by fine to medium sand-sized quartz grains, glauconite grains, calcite ooids, ferruginized ooids and coated grains, and extraclasts (reworked fragments of previously lithified rocks). The latter include rock fragments derived from the underlying Fe-rich crust, from limestones deposited during the stage 1 , and from older sandstone units. Quartz grains may represent 5 to $30 \%$ of the whole components, are sub-angular to subrounded in shape, and show moderate sorting. Plant fragments are a minor but ubiquitous component.

Ooids and coated grains are fine to medium-grained, moderately to poorly sorted and well-rounded (Fig. 12C-E). The nuclei consist of quartz grains, chert, extraclasts, echinoid plates, and abraded 

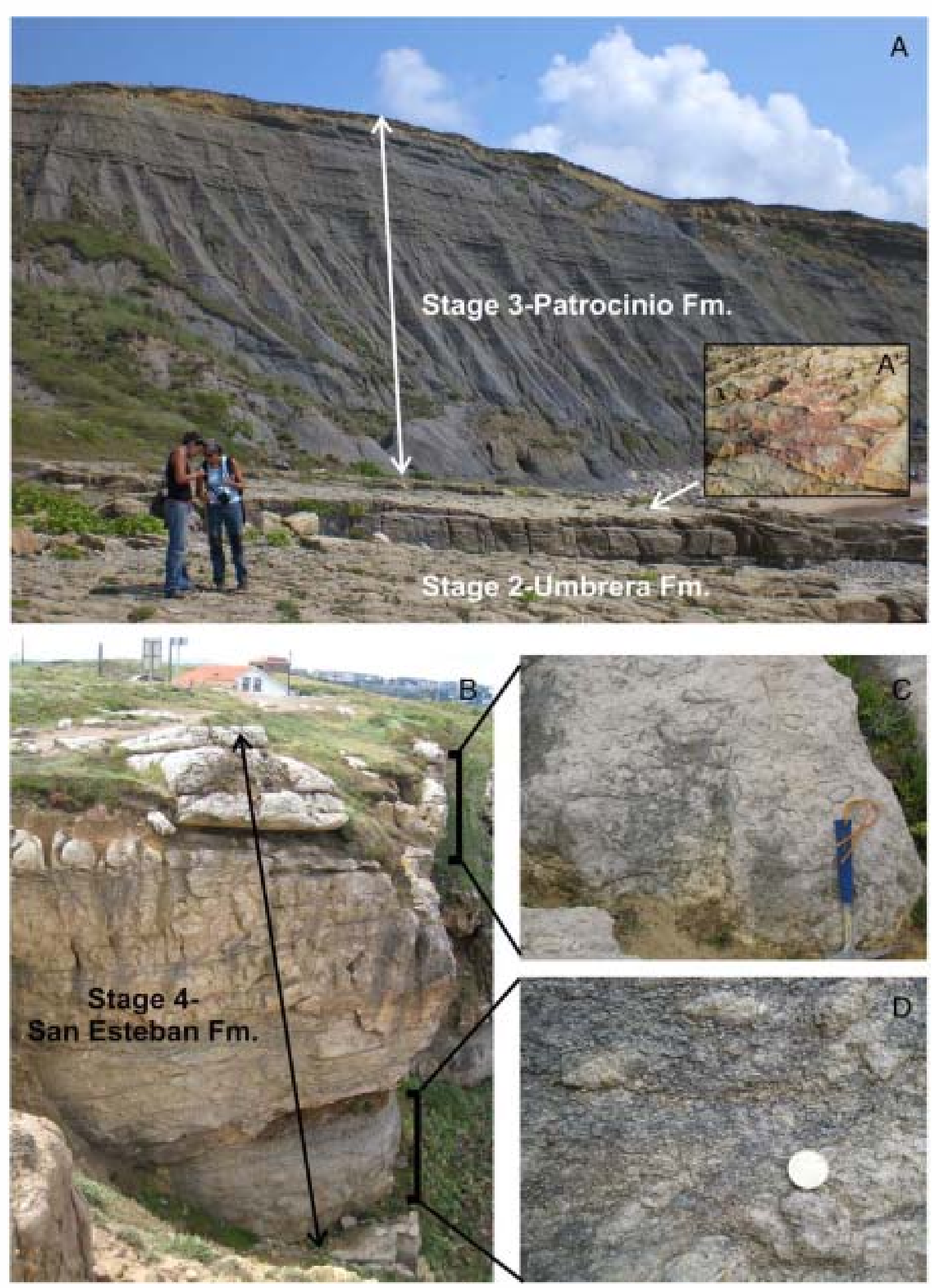

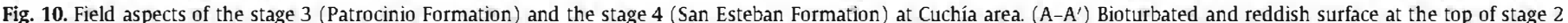

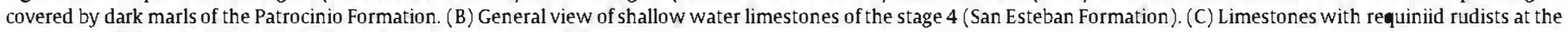
upper part of the unit. (D) Orbitolinid marls at the lower part of the unit. 


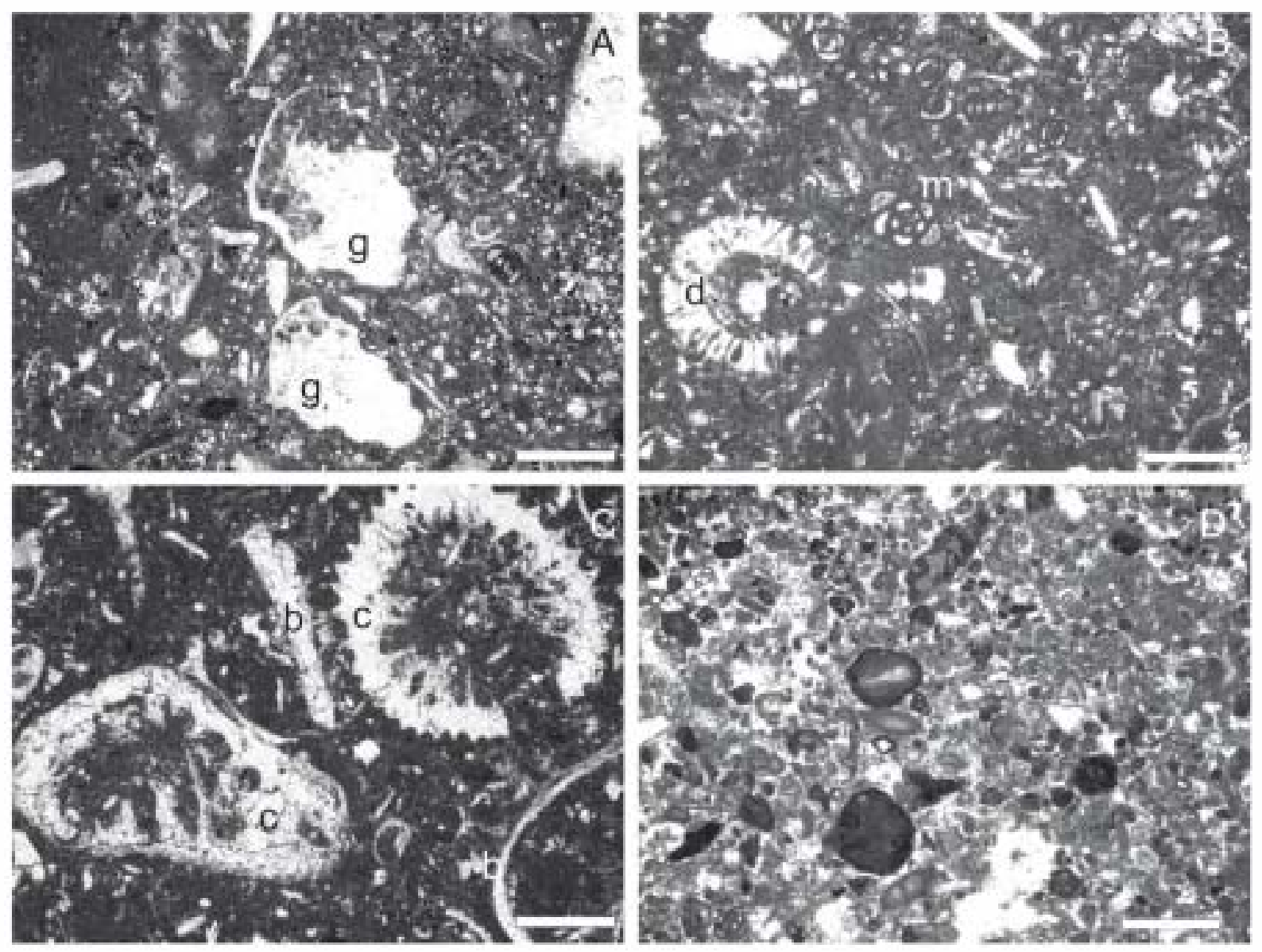

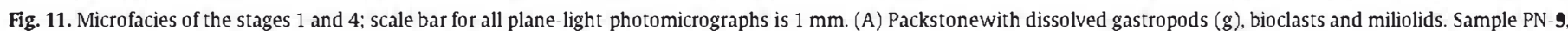

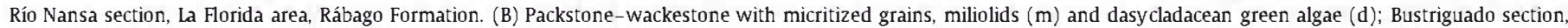

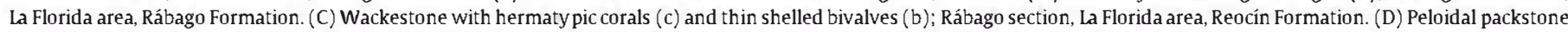
with intraclasts formed by micritic limestones, foraminiferans and bioclasts. Sample LA-7, Rábago section, La Florida area, Rábago Formation.

fragments of corals and bioclasts that generally appear dissolved and replaced by calcite (Fig. 12C). It has been distinguished both superficial and well-developed (normal) ooids with thick mixed cortices. Irregular concentric cortices of one or two layers form superficial ooids. Mixed ooids are common and result from the superposition of cortices made of both tangential calcite and micrite layers (Fig. 12E). In addition, ooids formed entirely by layers of tangential arrangement of tightly packed radial calcite crystals, and micritic ooids made of concentric micrite layered structures have been observed. Some composed ooids with two or more nuclei also occur. Some ooid cortices appear broken and separated from the nucleus or other cortices by thin calcite cement (Fig. 12C). Cracked ooids also occur, which may develop new cortices in discordance with the broken ones.

Glauconite beds occur in the upper part of the calcarenite succession, appearing as detrital grains, filling pore spaces, or replacing skeletal particles (Fig. 12F).

\section{Early diagenesis}

The study of thin sections under optical and CL microscopy allows differentiation of a series of diagenetic features which reveal essential aspects of early diagenesis. These notably complete the environmental information given by facies and fossils, and contribute to reconstruct the evolution of the platform, especially during the stages 1 and 2 , that preceded the OAE $1 \mathrm{a}$.

\subsection{Micritization}

During the stage 1 , bioclasts commonly present micrite rims or appear completely micritized. Both desuctive and constructive micrite envelops are observed. Micrite envelops and micritization also occurred during the stage 2 affecting to skeletal particles and ooids.

Destructive micrite envelopes are formed by microboring produced by microendolithic organism and infilling of the tiny little voids by microcrystalline $\mathrm{Mg}$ calcite or aragonite cements (Bathurst, 1966; Perry, 1999). Constructive micrite envelopes may result from the growth of externally calcified filamentous algae on the surface of the carbonate grains (e.g. Calvet, 1982). Both modes are interpreted to be connected with the activity of microbes, algae and fungi (Perry, 1999; Flügel, 2004; Chacón et al., 2006) and represent microbial development on the bioclastic debris. The micritized ooids are considered as the result of intense micritization of radial calcite ooids, caused by microboring by algae or fungi (Margolis and Rex, 1971).

\subsection{Ferruginization}

Concentration of iron oxide occurred on the ferruginous crust that coated the palaeokarst surface on top of the stage 1 . It is made by serpulid worm tubes and encrusting agglutinated foraminifera (nubeculariids) embedded in a matrix of iron-oxide films (Fig. 13A). In addition, red to brown grainstone beds with abundant iron-stained components occurred in the first metres above this surface. Iron staining affects to echinoderm fragments, foraminifera and bryozoan chambers 

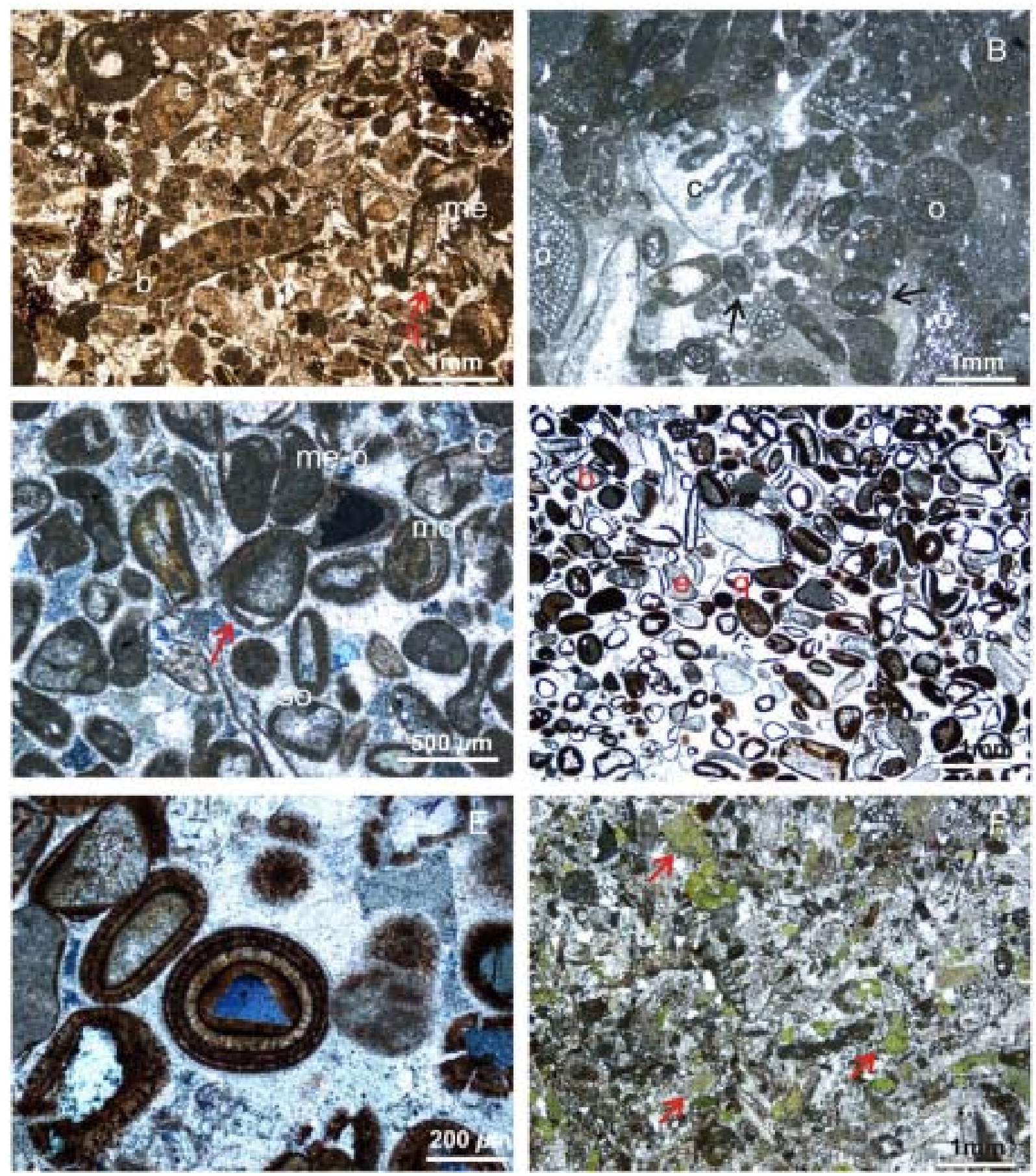

Fig. 12. Photomicrographs showingmicrofacies of the stage 2 (UmbreraFormation.). (A) Bioclastic grainstone with bryozoans (b), plates of echinoderms (e), micritized bioclasts (me) and quartz grains (q); Bustriguado section, La Florida area. (B) Packstonewith orbitolinids (o) and abraded fragments of corals (c) and miliolids (arrows); Cuchía section, Cuchíaarea. (C) Oolitic grainstone with mixed ooids (mo), superficial ooids (so) and micritized ooids (me-o). Note the broken ooid cortex separated from the nucleus by thin calcite cement (arrow); crossed polarized-light; La Florida section, La Florida area (D) Ferruginized oolites with different ty pes of nucleus such as quartz grains ( $\mathbf{q}$ ), echinoderm (e) and dissolved bioclast (b), and iron oxide or iron-stained cortices; Bustriguado section, La Florida area (E) Detail of a mixed ooid whose nucleus is composed by a quartz-grain and the cortex by layers of iron oxides and calcite; Bustriguado section, La Florida area; crossed polarized-light. (F) Glauconite-rich grainstone with quartz grains and bioclasts. Glauconite appears as detrital grains and replacing echinoderm plates (arrow); Cuchía section, Cuchía area.

and ooids. In these reddish beds, the cortex and nucleus of the majority of the ooids are strongly ferruginized and present abundant microborings and microfilaments (Fig. 13B-D), which may have destroyed completely the original textural pattems. The iron oxides may replace the external calcite cortices only or may form mixed ooids. Mixed ooids are formed by tangential calcite or fine micrite layers that alternate with thin Fe-rich coatings (Fig. 13B, C).

Ferruginized ooids and crusts similar to those described above are frequent inJurassic hardgrounds and condensed sections of the Tethyan basins (e.g. Di Stefano and Mindszenty, 2000; Préat et al., 2000; Rama jo et al., 2002; Gradzinski et al., 2004; Mamet and Préat, 2006; Reolid et al., 2008), but are identified throughout the whole stratigraphic record since the Proterozoic. Their genesis has been interpreted in diverse ways that include subaerial and submarine environments, with the iron being supplied from volcanic to hydrothermal, lateritic or continental sources (e.g. Jenlsyns, 1970; Nahon et al, 1980; Kearsley, 1989; Aurell et al., 1994; Sturesson et al., 2000). In this study, the presence of serpulids and encrusting foraminifera in the iron films and the marine nature of most 


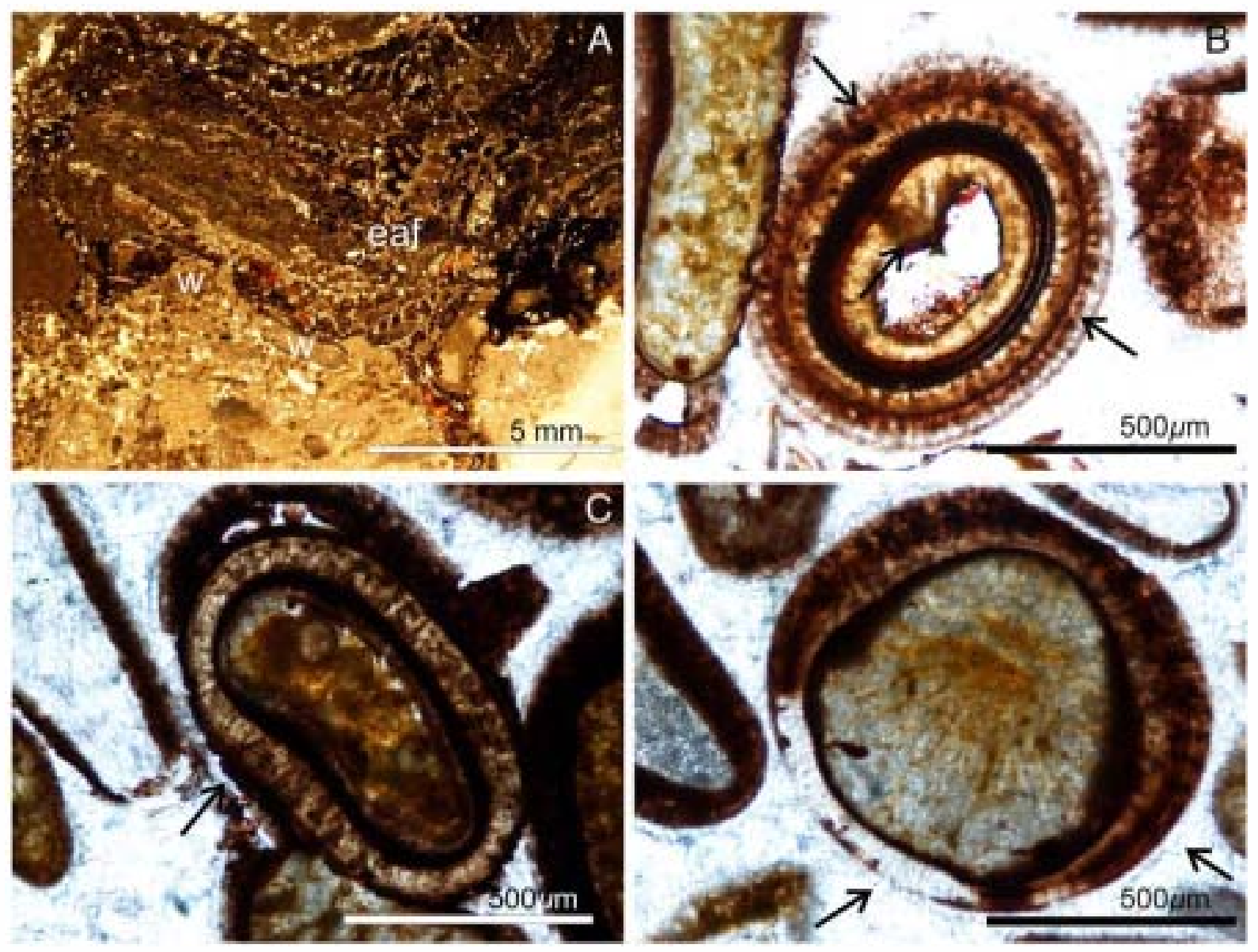

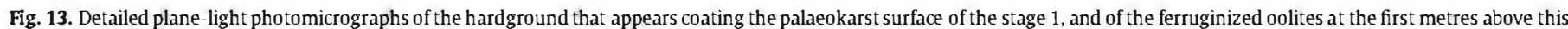

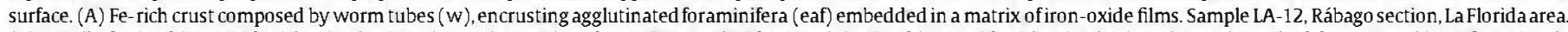

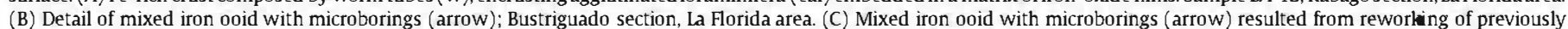

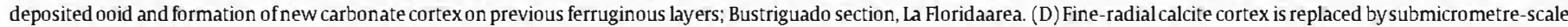
iron oxides. Note the isopachous, fibrous-to-bladed calcite cement ( $\mathrm{C} 1$ ) around the ferruginized ooid (arrows).

ooid nuclei indicate a definitive marine origin for the iron crust and ooids. The fact that the iron staining is related to bioclast and ooid portions which have lost the original texture suggests the presence of microbes that oxidized the ferrous iron. This may have occurred at the sediment-water interface (Préat et al., 2000), but implies that water energy at the sea bottom varied intermittently. Once the calcite ooids were formed, they rested on the sea-floor during a time interval long enough to allow that the original calcite surfaces of the ooids provide substratum for colonization of iron-oxidizing bacteria and fungi, forming colonies within the carbonate cortex. The microbial activity led to precipitation and replacement of the carbonate support by submicrometric iron oxides, and the ooids became reddish (Fig. 13D). This is an early marine diagenetic process that occurred at slowrates and that requires a relatively large exposition of the ooids near the sediment-water interface. After that, the ferruginized ooids may be reworked during subsequent episodes of high energy, or may be latterly transported to the high-energy depositional settings of stage 2. Mixed ooids may result from reworking of previously deposited and ferruginized ooids affected by later formation of a new carbonate cortex on old ferruginous layers (Fig. 13C).

\subsection{Glauconite authigenesis}

Glauconite cement has been observed in the stage 2, filling primary intraparticle voids, particularly within echinoderms and orbitolinids.
This authigenic glauconite is considered to have been precipitated from marine pore waters during early marine diagenesis, under low sedimentary rates and partially reducing conditions (Odin and Matter, 1981 ), and indicates primary mineralization in condensed marine sediments (Odin, 1988; Glenn et al., 1994).

\subsection{Carbonate cementation}

Carbonate cementation affects all the analyzed samples from a variety of diagenetic processes extending from early marine diagenesis on the sea-floor to meteoric and burial environments. Only the sea-floor and meteoric diagenetic stages are discussed in this paper. These carbonate cements appear as pore-lining and pore-filling cements in primary cavities, intergranular pore space, and in secondary mouldic porosity.

\subsubsection{Early marine cement}

Isopachous, fibrous-to-bladed calcite cement (C1) appears around ferruginized ooids, skeletal grains, quartz particles and extraclasts, associated preferably to the grainstone of the stage 2 of carbonate production. Isopachous fringing cement is also observed on samples from the stages 1 and 4, although it occurs more scarcely. This cement stains pink (non-ferroan) and fills primaryintergranular porosity. Under cathodoluminescence (C), it is bright to dull orange (Fig. 14A-B).

This calcite cement appears to have formed early, in the marine phreatic or near sea-floor environment as high-Mg calcite or fibrous aragonite, and later transformed to low-Mg calcite (Moore, 1989; 

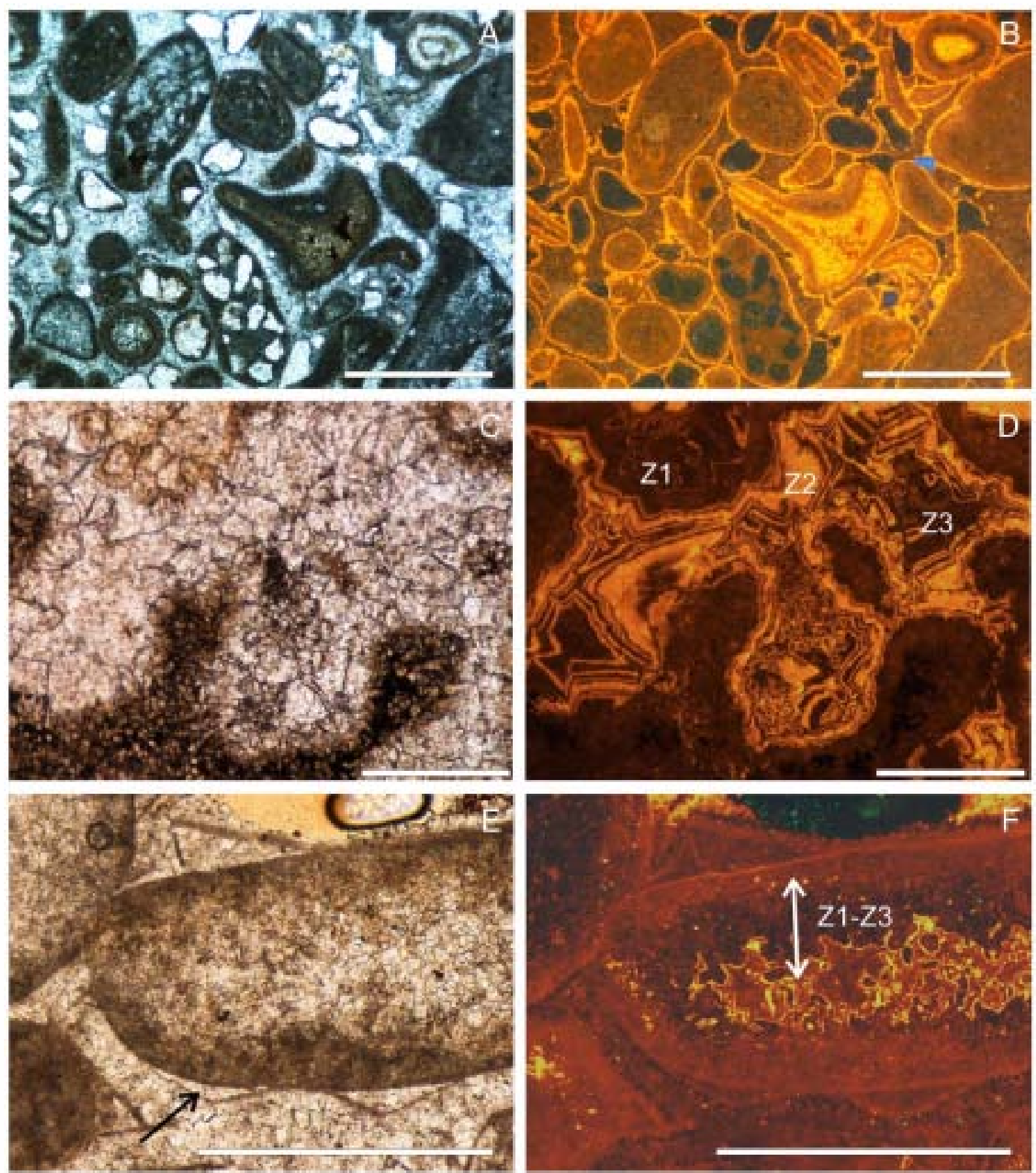

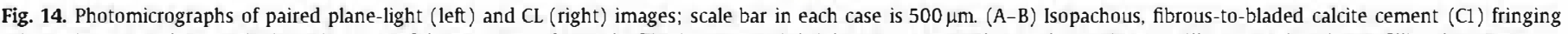

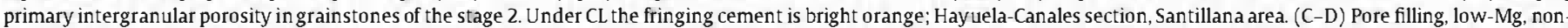

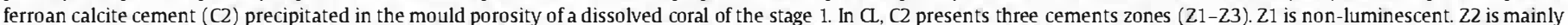

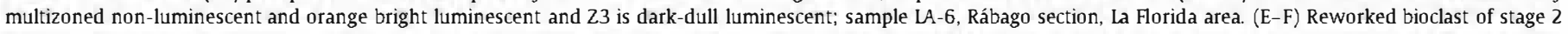

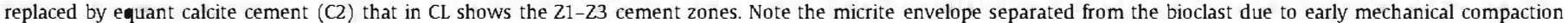
(arrow); Sample LA-12, Rábago section, La Florida area.

James and Choquette, 1990). The luminescence bright-dull orange suggests recrystallization or primary precipitation under slightly reducing conditions (Barbin, 2000). However, the regular pattern and homogeneous intensity of luminescence point to a rather primary precipitation.

\subsubsection{Shallow burial meteoric cement}

Blocky equant calcite spar (C2) occurs as pore-lining and porefilling cement in primary inter- and intraparticle pores as well as in secondary mouldic porosity. This cement commonly occurs as scalenohedral (dogtooth) spar around pores or as drusy to equant calcite when occluding pore spaces. It is non-ferroan and probably low-Mg, and is rich in Fe-oxide solid inclusions. In CL this cement presents three cements zones ( $\mathrm{Z} 1$ to $\mathrm{Z3}$; Fig. 14C-D). Z1 is nonluminescent. $\mathrm{Z2}$ is mainly orange- to yellow bright luminescent, and may occur as one single bright zone or as several bright luminescent/ non-luminescent multizones (Fig. 14D). 23 zone is dark-dull luminescent.

Spar crystals of calcite $\mathrm{C} 2$ have been observed in all the carbonate stages. However, there is a significant difference in how calcite $\mathrm{C} 2$ 
appears through the succession, especially through the stages 1 and 2 . Beneath the unconformity at the top of stage 1, this calcite spar occurs extensively in intergranular, shelter, intraskeletal and mouldic pores, the later generated after leaching of aragonite skeletons. In contrast, above the unconformity, $\mathrm{C} 2$ calcite does not cement grainstones of the stage 2 (Fig. 14E-F). In this case, it is observed only in some abraded skeletal grains, eroded and reworked from the previous stage 1 (Fig. 14E-F).

Calcite spar $\mathrm{C} 2$ is considered to indicate freshwater shallow burial (meteoric) cementation from oxidizing (non-luminescent) to moderate reducing (bright luminescent) pore fluids (Moore, 1989; Muchez et al., 1998; Dickson and Saller, 1995; Mutti, 1995). This process is well documented in modern aquifers (Champ et al., 1979). Leaching of the aragonite skeletons and subsequent replacement by calcite spar C2 occurred during emersion at the end of stage 1. During the following transgression, with erosion of the previous stage, they were eroded and recycled in the grainstones of the stage 2 .

\section{Stable isotopes}

Stable carbon isotopic composition $\left(\delta^{13} \mathrm{C}\right)$ throughout the studied succession in La Florida area (Fig. 15), varies from $+3.6 \%$ o to $-4.5 \%$, recording a noticeable range of variability, which exceeds $8 \%$. In that succession, the $\delta^{13} \mathrm{C}$ record can be subdivided into three successive intervals (Fig. 15). The basal interval matches with stages 1 and 2 of carbonate production. It shows relatively homogeneous and positive ${ }^{13} \mathrm{C}$ values during the stage 1 (mean of $+2.2 \%$ ), and a significant and progressive decrease (of about 1\%) in the record of the stage 2 (but still within positive values). The second interval of the ${ }^{13} \mathrm{C}$ curve correlates with the Patrocinio Formation (stage 3). This interval is characterized by a notable negative excursion from values of $-0.4 \%$ at the base of the interval to $-4.5 \%$ at the top. The decrease in the values is not gradual but shows three negative peaks $(-2.9 \%,-4.1 \%$ 。 and $-4.5 \%$ respectively; Fig. 15). Finally, the third interval in the $\delta^{13} \mathrm{C}$ record shows the return to positive values. This change occurs during the re-instauration of carbonate production in the stage 4 . During this interval the $\delta^{13} \mathrm{C}$ values range from $+2.5 \%$ to $+3.6 \%$, and are, in average, more positive than those of the first interval.

The oxygen-isotope record $\left(\delta^{18} \mathrm{O}\right)$ also shows a remarkable variability, with values varying from $-2.7 \%$ o to $-13.8 \%$ 。(Fig. 15). It reveals comparable patterns to those of the carbon-isotope curve, and three main intervals can be also differentiated along the section. The first interval coincides with the stages 1 and 2, and presents relatively constant values (mean of $-3.5 \%$ ). A sharp negative excursion is recorded during deposition of the marly Patrocinio Formation. Here the values range from $-5.7 \%$ 。 to $-13.8 \%$. The third interval of the $\delta^{18} \mathrm{O}$ curve shows a return to less negative values (mean of $-4.3 \%$ ), which are correlated with deposition of the stage 4 (Fig. 15).

\section{Discussion}

Understanding the effects of the OAEs in the deep oceans has become a major objective of a large number of works in the last years. However, little is still known about the effects of these events on shallow marine platform carbonates and the interaction of their effects with local tectonic factors. The studied shallow platform succession was affected during the Aptian by the OAE 1a and by extensional tectonics. During the Aptian and immediately preceding

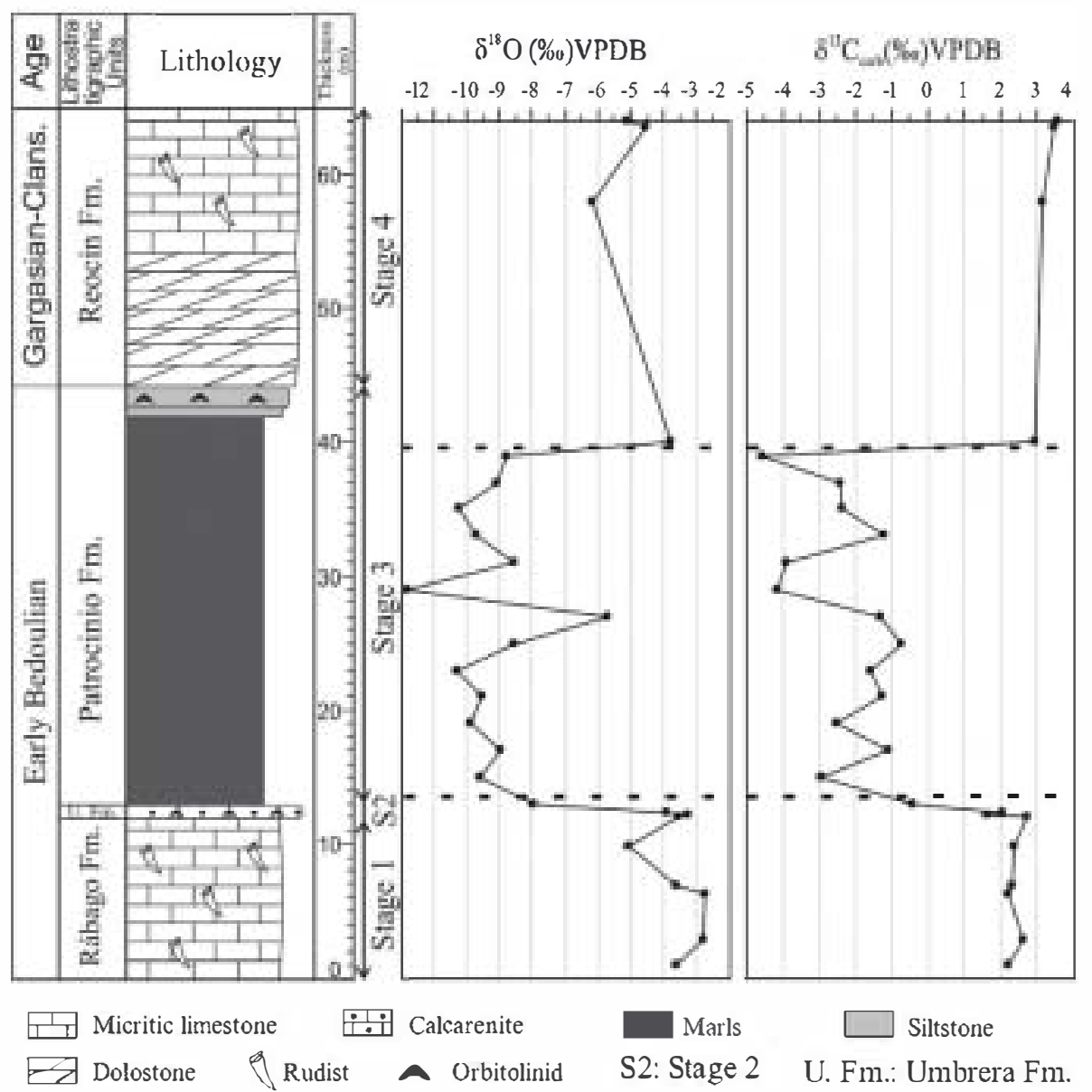

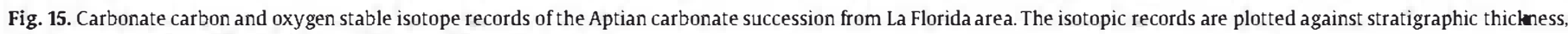
lithology and stratigraphic units. Dotted lines mark isotopic intervals. 
the anoxic event, the platform evolved from stage 1 (photozoan assemblages) to stage 2 (heterozoan assemblages) of carbonate production. Later, a rapid drowning of the platform and deposition of open-marine shales (stage 3) occurred at the onset of the OAE $1 \mathrm{a}$. Finally, the recovering of shallow water carbonate deposition with photozoan assemblages took place during the stage 4 , at the end and after the anoxic event. The data indicate that the stratigraphic, sedimentological, diagenetic and chemostratigraphic shifts that affected the platform carbonates during this time were abrupt, and all of them point to rapid environmental changes accompanying the platform evolution.

\subsection{Photozoan versus heterozoan styles of carbonate production}

The predominance during the carbonate stages 1 and 4 of lightdependent benthic organisms and skeletal grain types (corals, dasycladacean algae, etc.) indicates a photozoan style of carbonate production (Table 1). Comparing with modern carbonate sediments, this photozoan assemblage reflects favourable platform growth conditions in seawaters that are shallow, transparent, warm, euhaline, and oligotrophic (Hallock, 1988; Föllmi et al., 1994; James, 1997). The photozoan textures (wackestone and packstone) of stages 1 and 4 suggest that the depositional energy was predominantly low. The presence of miliolids, monopleurid and requieniid rudist banks, L. aggregatum- $B$. irregularis, and fenestral microbialites suggests shallow water with stable bottom conditions and deposition in protected lagoons with weak bottom currents (e.g. Ross and Skelton, 1993; Gómez-Pérez et al., 1998), only occasionally affected by highenergy episodes. The low amount of non-skeletal grains and the minor contribution of siliciclastic particles, except for the mixed carbonate-siliciclastic facies at the transgressive bases of the carbonate stages, suggest low contribution of terrigenous runoff during these stages of carbonate growth.

In contrast, during the stage 2 , the platform sedimentation was dominated by a heterozoan style of carbonate production, with predominance of calcite components, absence of organic build-ups, and abundance of suspension feedings such as crinoids and bryozoans. The substantial amount of orbitolinids indicates conditions of high nutrient input, since these asexually reproducing benthic foraminifera thrive in such conditions (Birkeland, 1988; Vilas et al., 1995). The heterozoan skeletal grains of the stage 2 (e.g. echinoids, coralline algae and molluscs) are ubiquitous elements present in a wide range of shallow marine systems and latitudes, although they became predominant only when other organisms are inhibited by environmental conditions such as light availability, temperature, salinity and nutrients (Hallock, 1988). In modern platform analogues, this heterozoan association typifies sedimentation in cool waters, or alternatively, sedimentation below the photic zone (James, 1997). However, nutrient poisoning (excess) can produce enough environmental stress to radically alter the platform benthos and eventually led to platform drowning (Hallock and Schlager, 1986; Hallock, 1988; Jenkyns, 1995). During the Aptian, sedimentation in the BasqueCantabrian basin occurred in warm, sub-tropical climatic regions (e.g. Scotesse et al., 1998), and the data indicate that both the photozoan and heterozoan stages of carbonate deposition took place in shallow water conditions. The presence of light-dependent organisms in the photozoan stages implies deposition within the photic zone. In the heterozoan stage 2, the overall lack of carbonate mud, the common high-energy traction current structures, and the presence of oolites suggest deposition under agitated bottom waters, likely within the photic zone as well. Therefore, depth seems not to have played a major role in the compositional shifting to heterozoan carbonate sedimentation during the stage 2 . The presence of substantial amounts of sand-sized siliciclastic particles accompanying the heterozoan stage 2 may be considered as an indicator of higher nutrient influx levels accompanying the import of detrital particles in this stage that preceded the OAE 1a (Föllmi et al., 1994; Burla et al., 2008).

Recently, there is an open debate about a possible causal relationship between the presence of Lithocodium-Bacinella communities in shallow epicontinental seas and the OAE 1a (Immenhauser et al., 2005). According to these authors, the Lithocodium-Bacinella consortium may represent an out-of-balance facies, flourished under rising nutrient levels, which are time-equivalent in shallow water platforms to the black shales deposited in hemipelagic and pelagic environments during the OAE 1a (Immenhauser et al., 2005). However, in this study the presence of Lithocodium-Bacinella communities is not related with the OAE $1 \mathrm{a}$. In fact, this facies appears indistinctly before and after the OAE $1 \mathrm{a}$, (stages 1 and 4) with the maximum bloom taking place during the Late Aptian (Reocin Formation), which is not time-equivalent with the OAE 1a. On the contrary, the time-equivalent facies at the onset of the OAE 1a are represented by the black marls of the stage 3 (Patrocinio Formation) deposited during transgression and drowning of the platform.

\subsection{Ferruginization, glauconite, and environmental stress}

The shifting from the photozoan stage 1 to the heterozoan stage 2 was marked by a subaerial exposure surface coated by a later submarine iron crust; and the heterozoan skeletal association of stage 2 was accompanied by formation of ferruginized oolites. The ferruginous crust indicates early sea-floor cementation resulting in a hard ground-capped unconformity, likely related to iron bacteria and microbe activity. This is suggested by the existence of microborings filled with iron oxides. The presence of nubeculariid foraminifers may suggest relatively shallow warm waters (Gradzinski et al., 2004).

Ferruginization of previous calcite oolites resulting in the formation of ferruginized oolites took place also under the influence of iron-oxidizing bacteria. This process can be produced by a variety of both phototrophic and non-phototrophic microorganisms. Due to the lack of light dependence of these organisms, they probably formed under dim conditions and required slow sedimentation rates, the presence of low-oxygen water masses and a source of iron (Mamet and Préat, 2006; Préat et al., 2008). Such conditions were likely associated with dysaerobic sediment-water interfaces (Mamet and Préat, 2006). Under such conditions the stability of the soluble reduced state of iron is higher and the metabolic activity of Feoxidizing bacteria can induce ferric oxide and hydroxide precipitation as a secondary by-product (Konhauser, 1998; Mamet and Préat, 2006). Therefore, these ferruginized oolites suggest the existence of long periods with dysaerobic bottom conditions that would alternate with high-energy conditions where the cross-stratified grainstones were formed. As indicated by the presence of some oolites with mixed layers of iron oxides and calcite, iron precipitation occurred probably very early, just after formation of oolite calcite cortices and fragmentation of skeletons and their immediate deposition, although they were still susceptible of periodic reworking. The source of the iron mineral can be explained by a terrigenous origin, with the iron derived from enhanced continental weathering during sedimentation.

The formation of both hardground surfaces coated with iron oxide and glauconite-bearing sediments is frequent in the geological record related to condensed series and submarine hiatuses, and their genesis appear to be directly related to rapid sea-level rises, carbonate platform destruction and eutrophication (Hallock and Schlager, 1986; Hallock, 1988; Föllmi et al., 1994). The data suggest that enhanced terrestrial runoff during the stage 2 of carbonate production probably brought iron and nutrients to the North Cantabrian platform, resulting in water-column eutrophication and environmental stress. These particular trophic conditions may explain the proliferation of heterotrophic Fe-oxidizing bacteria and suspension-feeding benthic organisms, such as crinoids and other heterozoan skeletal components of the stage 2 (James, 1997; Föllmi et al., 2006). 


\subsection{Early calcite cements and environmental conditions of stages 1 and 2}

The analysis of diagenetic features in the carbonates has been of great value to recognize meteoric alteration of the platform carbonates and to provide an additional record of changes in relative sea-level and environmental conditions. The occurrence of precompaction, calcite spar $\mathrm{C} 2$ is interpreted to precipitate from oxidized to slightly reduced meteoric waters in the phreatic zone (e.g. Benito et al., 2005; Bishop et al., 2009). Early meteoric cements have been exclusively observed on samples from the stage 1, accompanying medium-scale karstic features that occur at the top of this stage. The meteoric fluids entered the platform as a result of a combination of both subaerial exposure and acceleration of the hydrological cycle, which induced increased rainfall, fluvial discharge, and continental runoff. The interaction of meteoric waters with exposed marine carbonates during platform emersion caused dissolution and favoured the circulation of freshwater lenses through the carbonate mass, which acted as an unconfined aquifer. This resulted in further dissolution and precipitation of the non-luminescent to bright luminescent (Z1-Z2) blocky spar, filling all available porosity (primary cavities and secondary mouldic porosity). It should be noted that the occurrence of these type of cements recognized in some of the basal samples of the stage 2 is only apparent, as they are always found in recycled and reworked lithoclasts from the previous stage.

Primary intergranular porosity in grainstones from the stage 2 was filled with rinds of marine isopachous calcite cements, which precipitated primary most likely as luminescent cements. Manganese is the most common activator of the luminescence in natural calcites (Marshall, 1988) and its incorporation in marine cements may suggest changes in the trace element concentration of the seawater or changes in the redox environmental conditions of precipitation (Barbin, 2000). Besides, the influx of freshwater may increase the Mn content of seawater and, therefore, of the calcite precipitated under such environmental conditions. For example, cathodoluminescence studies carried out on recent biogenic calcites have revealed an increase of luminescence and Mn contents of the shell calcites with decreasing salinity (Barbin et al., 1991).

\subsection{Platform drowning and negative $C$ and $O$ isotope excursions of stage 3}

The platform drowned during the evolutionary stage 3 . The age of the drowning episode is well constrained with ammonites, planktonic foraminifers and nannofossils (Fig. 4), confirming that the marly interval (Patrocinio Formation) corresponds unequivocally to the OAE 1a (Gea et al., 2003; Rosales et al., 2009; Moreno-Bedmar et al., 2009). The chemostratigraphic analyses have revealed a prominent negative shift $(\sim 6 \%)$ in the carbon-isotope record during deposition of these open-marine black marls. This negative shift is very similar to those reported from other coeval sections from adjacent basins (e.g. Moreno-Bedmar et al., 2009) and other basins from Europe, North America, Japan and the Pacific Ocean (Menegatti et al., 1998; Erba et al., 1999; Gröcke et al., 1999; Jenkyns and Wilson, 1999; Luciani et al., 2001; Ando et al., 2002; Bellanca et al., 2002; Jenkyns, 2003; Weissert and Erba, 2004, Burla et al., 2008), and is defined as a distinctive feature of the onset of the OAE 1a. Although the possible causal mechanisms of this carbon-isotope negative excursion are under a controversial debate (Jahren et al., 2001; Beerling et al., 2002; Jenkyns, 2003; Milkov, 2004), the massive release of isotopically light carbon to the atmosphere/hydrosphere reservoirs from methane hydrate dissociation is regarded as the most plausible hypothesis. This release was probably triggered by intensive volcanism and formation of large igneous provinces (Larson and Erba, 1999).

There is a good correlation between the ${ }^{13} \mathrm{C}$ record of the studied Aptian carbonates and the main changes occurring in the evolution of the platform. The photozoan stages 1 and 4 are characterized by $\delta^{13} \mathrm{C}$ values typical of micritic limestones from carbonate platforms of this period (Menegatti et al., 1998; Burla et al., 2008). The installation of the heterozoan stage 2 is correlated with a slight shift to more negative ${ }^{13} \mathrm{C}$ values before the sharp negative spike that characterize the stage 3 of platform drowning and the onset of the OAE $1 \mathrm{a}$. Similar correlations of ${ }^{13} \mathrm{C}$ negative shifts and phases of heterozoan carbonate growth have been also described for other Early Cretaceous Tethyan platforms (Föllmi et al., 2006). The cause of this correlation is unclear but may be influenced in some degree by the input to the basin of continental water rich in dissolved isotopically light carbon derived from soil erosion.

The oxygen-isotope record during the stage 3 of platform drowning shows also a prominent shift (up to $11 \%$ ) to more negative values accompanying the $\mathrm{C}$-isotope negative spike. Generally, relative low $\delta^{18} \mathrm{O}$ values in pristine marine calcites are explained as reflecting elevated seawater temperatures (e.g. Marshall, 1992). However, the negative $\delta^{18} \mathrm{O}$ values registered during the stage 3 are incompatible with any reasonable palaeotemperature reconstruction since, if interpreted only in terms of palaeotemperature, would give unrealistic extremely high seawater temperatures. New $\delta^{18} \mathrm{O}$ data on pelagic carbonates from ODP survey in the central Pacific (Ando et al., 2008) has revealed extreme warming at the onset of the OAE $1 \mathrm{a}$, with $\delta^{18} \mathrm{O}$ pelagic values as low as $-4.5 \%$ departing from background values of about $-2 \%$. By comparison, only a small portion $(\sim 2-3 \%$ ) of the isotopic shift recorded in the samples across the marly interval of stage 3 may have been caused by this warming episode.

Other possible mechanism to explain isotopically light values of both $\delta^{18} \mathrm{O}$ and $\delta^{13} \mathrm{C}$ records in shallow platform carbonates can be found in early diagenetic processes associated with platform exposure (Immenhauser et al., 2002, 2003, 2008). These authors propose that low $\mathrm{C}$ and $\mathrm{O}$ isotope values in platforms tops are usually related to the combination of two processes. One is the influence of ${ }^{18} \mathrm{O}$-depleted early meteoric fluids and the other is the influence of ${ }^{13} \mathrm{C}$-depleted soil-zone $\mathrm{CO}_{2}$ during carbonate recrystallization. However, in this study the negative shifts in $\mathrm{C}$ and $\mathrm{O}$ isotopes are not recorded in the shallow platform carbonates but in the open-marine marls of the Patrocinio Formation, which deposited during widespread transgression under water-depth conditions far from subaerial exposure.

More plausible, secondary changes in the isotope ratios could occur with carbonate recrystallization during burial diagenesis, and could explain at least the anomalous low $\delta^{18} \mathrm{O}$ values. Early precipitation of diagenetic isotopically light calcite in the marly interval as a consequence of bacterial organic matter decomposition in the sulphate-reducing zone is likely a mechanism that operated in many organic-rich rocks (Sass et al., 1991). However, the scarcity of organic matter present in our samples $(0.5 \%$ or less; Rosales et al., 2009) may compromise this interpretation. Alternatively, depletion in the $\delta^{18} \mathrm{O}$ and $\delta^{13} \mathrm{C}$ composition of the seawater may have been caused by an influx of terrestrial runoff into the platform during the stage 3 as a consequence of acceleration of the hydrological cycle (e.g. as described in the Early Toarcian OAE by Sælen et al., 1996). The change in the isotope composition of the platform seawater during this stage may have acted in combination with the warming episode (Ando et al., 2008) to cause the low $\delta^{18} \mathrm{O}$ values detected in the samples.

\subsection{Climate (global) versus tectonic (local) controls on the platform evolution}

Beyond the influence of the OAE $1 \mathrm{a}$, the described patterns of platform evolution in the NCB are also influenced by regional factors such as local tectonics and differential subsidence or runoff changes. Eustacy also should play a significant role in the evolution of the platform.

Regionally, rift tectonism occurred during the Tithonian-Cenomanian (e.g. Martin-Chivelet et al., 2002). The syn-rift nature of the carbonate succession deposited during the Aptian in the NCB is indicated by the fact that strata thicken and fan out into hangingwall areas and thin onto 
footwall areas (Figs. 2B and 5). Therefore, it can be assumed that the accommodation space for platform growth was created from a combination of sea-level change, local block movements, and regional subsidence from crustal thinning and sediment loading.

The contact between the carbonate platform stage 1 and the next stage 2, which is marked by an unconformity with evidence of erosion, dissolution and meteoric diagenesis on footwall crests, points to local uplift and a brief period of subaerial exposure. The stage 2 was a carbonate sequence developed initially only on the more subsiding parts of the basin. The unit shows pronounced onlap at the base and is interpreted as the passive fill of a wedge-shape accommodation space during a phase of relative sea-level rise. This stratigraphic pattern closely resembles the depositional architecture predicted by the models of Bosence (2005) and Gardner et al. (2009) for fault-block carbonate platforms, and suggests that local tectonics was the major cause of this unconformity that produced hangingwall subsidence and footwall uplift. The flooding and onlapping on this surface were accompanied by the change to a heterozoan style of carbonate production with influx of siliciclastic particles. The predominance of such type of grains, and the rest of evidences presented in this study, all suggest environmental perturbation by continental waters charged in siliciclastic particles and nutrients, resulting in a mesotrophic habitat in the stage that preceded the OAE $1 \mathrm{a}$. The carbonate factory changed to a less-effective mode of sedimentation that occurred at slow rates, as indicated by the presence of glauconite, and the high rates of microbial activity and ferruginization. This sedimentary response may have been induced by the tectonic uplift and fluvial erosion of the southern and western margins of the NCB. However, deterioration of the shallow water carbonate systems occurred almost simultaneously worldwide, such in the Pacific (Jenkyns, 1995), France (Masse et al., 1999), Switzerland (Wissler et al., 2003), Helvetic Alps (Föllmi et al., 2006), and Portugal (Burla et al., 2008) among others, suggesting that this was an inter-regional phenomenon.

The shallow water carbonate platform deterioration took place during a rapid rise in relative sea-level. The weakened production rate of the carbonate stage 2 could not keep-up with the rising sea-level, with the consequent drowning of the platform and deposition of open-marine marls of the stage 3 . Although this event was influenced by tectonic subsidence, the early Aptian flooding should be considered as a major eustatic transgressive event. It is well recorded in other rifted-basins of both the Tethys and the North Atlantic, and remarkably, it has been also reported from cratonic areas, such as the East African craton, which are considered as geologically more stable (Bosellini et al., 1999). Because this transgression correlates well with similar events around the world and within different tectonostratigraphic settings (Somalia, Arabian Peninsula, Ethiopia, southern Italy, France, Spain, Portugal, north-eastern Mexico, Pacific realm, etc.) (e.g. Lehmann et al., 1999; Bosellini et al., 1999; Rosales, 1999; Burla et al., 2008; Föllmi, 2008), it is considered as a global phenomenon linked to the OAE 1a. Therefore, and in summary, in the $\mathrm{NCB}$, the proximity of emerged land areas to the south of the Cabuérniga Ridge and in the Asturian Massif (see Fig. 1C for location) along with a combination of tectonic movements and more humid climate conditions, would have increased continental erosion, river drainage and runoff, which ultimately would have been responsible for the local/regional platform eutrophication and the subsequent drowning that accompany the OAE $1 \mathrm{a}$.

\section{Conclusions}

The following conclusions from the study of the Early Aptian carbonate succession of the North Cantabrian basin can be drawn:

1) Four successive stages of carbonate production (1 to 4 ) outline the evolution of the platform, from which stage 3 corresponds to the local expression of the OAE $1 \mathrm{a}$.
2) The carbonate stages that preceded the OAE 1 a exhibit a compositional shifting from photozoan (stage 1) to heterozoan (stage 2) skeletal grains. These two stages of carbonate production are separated by an unconformity. This surface exhibits evidence of erosion, karstic dissolution and meteoric diagenesis, and is capped by a submarine ferruginous crust during the following transgressive event.

3) Tectonic activity favoured the influx of terrigenous particles from terrestrial runoff that accompanied the observed biotic changes. Besides, an accelerated hydrological cycle increased the input of freshwater and nutrients into the platform, causing the change from oligotrophic (stage 1) to mesotrophic (stage 2) conditions.

4) This event in the evolution of the carbonate platform correlates well with worldwide environmental deterioration of benthic environments. The combination of water freshening, nutrient poisoning, tectonic activity and rising eustatic sea-level may have acted together resulting in the progressive destabilisation of the marine environments and the change to less-effective carbonate factories (heterozoan), which may be the cause of the demise of many carbonate platforms worldwide previous to the instauration of the OAE.

5) Finally, the integration of sedimentological, diagenetic and chemostratigraphic analysis has been proven as a useful tool to identify and characterize global palaeoclimatic perturbations in shallow water carbonate platform environments.

\section{Acknowledgements}

This work is part of the Ph.D. Thesis of the first author (M.N.), who is supported by a scholarship from the Instituto Geológico y Minero de España (IGME). The study is a contribution to the DGI project CGL2008-01237/BTE (MICINN, Spanish Government), and to the UJA07-16-41 project (Jaén University, Spain). Many thanks are due to $A$ Immenhauser and D. Sanders for valuable scientific comments and suggestions to improve the original manuscript.

\section{References}

Ando, A., Kakegawa, T., Takashima, R., Saito, T., 2002. New perspective on Aptian carbon isotope stratigraphy: data from $\delta^{13} \mathrm{C}$ records of terrestrial organic matter. Geology $30,227-230$

Ando, A., Kaiho, K., Kawahata, H., Kakegawa, T., 2008. Timing and magnitude of Early Aptian extreme warming: unraveling primary $\mathbf{~}^{18} \mathrm{O}$ variation in indurated pelagic carbonates at Deep Sea Drilling Project Site 463, central Pacific Ocean. Palaeogeography, Palaeoclimatology, Palaeoecology 260, 463-476.

Arnaud-Vanneau, A. Arnaud, H., 1990. Hauterivian to Lower Aptian carbonate shelf sedimentation and sequence stratigraphy in the Jura and northern subalpine chains (southeastern France and Swiss Jura). In: Tucker, M.E., Wilson, J.L., Crevello, P.D., Sarg, J.R., Read, J.F. (Eds.), Carbonate Platforms: Facies, Sequences, and Evolution: IAS Special Publication, 9, pp. 203-233.

Aurell, M., Fernández-López, S., Meléndez, G., 1994. The Middle-Upper Jurassic oolitic ironstone bed in the Iberian Range (Spain). Eustatic implications. Geobios Mémoire Spéciale $17,549-561$

Barbin, V., 2000. Cathodoluminescence of carbonate shells: biochemical vs diagenetic process. In: PageI, M., Barbin, V., Blanc, Ph., Ohnenstetter, D. (Eds.), Cathodoluminescence in Geosciences, 12. Springer Verlag, pp. 303-329.

Barbin, V., Ramseyer, K., Debena, J.P., Schein, E., Roux, M., Decrouez, D., 1991 Cathodoluminescence of recent biogenic carbonates: an environmental and ontogenetic fingerprint. Geological Magazine 128, 19-26.

Bathurst, R.G.G., 1966. Boring algae, micrite envelops and lithification of molluscan biosparites. Geological Journal 5, 15-32.

Beerling, D.J., Iomas, M.R., Gröcke, D., 2002. On the nature of methane gas-hydrate dissociation during the Toarcian and Aptian oceanic anoxic events. American Journal of Sciences 302, 28-49.

Bellanca, A., Erba, E., Neri, R., Premoli-Silva, I., Sprovieri, M., Tremolada, F., Verga, D., 2002. Palaeoceanographic significance of the Tethyan 'Livello Selli' (Early Aptian) from the Hybla Formation, northwestern Sicily: biostratigraphy and highresolution chemostratigraphic records. Palaeogeography, Palaeoclimatology, Palaeoecology 185, 175-196.

Benito, M.L, Lohmann, K.C., Mas, R., 2005. Late Jurassic palaeogeography and palaeoclimate in the Northern Iberian Basin of Spain: constraints from diagenetic records in reefal and continental carbonates. Journal of Sedimentary Research 75, $82-96$

Birkeland, C, 1988. Second-order ecological effects of nutrient input into coral communities. Galaxea 7, 91-100. 
Bishop, J.W., Montañez, LP., Gulbranson, E.L., Brenkle, P.L., 2009. The onset of midCarboniferous glacio-eustasy: sedimentologic and diagenetic constrains, Arrow Canyon, Nevada. Palaeogeography, Palaeoclimatology, Palaeoeology 276, 217-243.

Bosence, D., 2005. A genetic classification of carbonate platforms based on their basinal and tectonic setting in the Cenozoic. Sedimentary Geology 175, 49-72.

Bosellini, A, Russo, A, Schroeder, R., 1999. Stratigraphic evidence for an Early Aptian sea-level fluctuation: the Graua Limestone of south-eastern Ethiopia. Cretaceous Research 20,783-791.

Burla, S., Heimhofer, U., Hochuli, P.A., Weissert, H., Skelton, P., 2008. Changes in sedimentary patterns of coastal and deep-sea successions from the North Atlantic (Portugal) linked to Early Cretaceous environmental change. Palaeogeography, Palaeoclimatology, Palaeoecology 257, 38-57.

Calvet, F., 1982. Constructive micrite envelope developed in vadose continental environment in Pleistocene eolianites of Mallorca (Spain). Acta Geológica Hispánica $17,169-178$.

Carannante, G., Cherchi, A, Simone, L., 1995. Chlorozoan versus foramol lithofacies in Upper Cretaceous rudist limestones. Palaeogeography, Palaeoclimatology, Palaeoecology 119, 137-154.

Chacón, E., Barrendero, E., García-Pichel, F., 2006. Biogeological signatures of microboring cyanobacterial communities in marine carbonates from Cabo Rojo, Puerto Rico. Sedimentary Geology 185, 215-228.

Champ, D.R., Gulens, J., Jackson, R.E., 1979. Oxidation-reduction sequences in ground water flow systems. Canadian Journal of Earth Sciences 16, 12-23.

Collignon, M., Pascal, A., Peybernès, B., Rey, J., 1979. Faunes d'ámmonites de I'Aptien de la Région de Santander (Espagne). Annales de Paléontologie 65, 139-156.

Di Stefano, P., Mindszenty, A, 2000. Fe-Mn-encrusted "Kamenitza" and associated features in the Jurassic of Monte Kumeta (Sicily): subaerial and/or submarine dissolution? Sedimentary Geology 132, 37-68.

Dickson, J.A.D., 1966. Carbonate identification and genesis as revealed by staining. Journal of Sedimentary Petrology 36, 491-505.

Dickson, J.A.D., Saller, A.H., 1995. Identification of subaerial exposure surfaces and porosity preservation in Pennylvanian and Lower Permian shelf limestones, eastern Central basin Platform, Texas. In: Budd, D.A., Saller, A.H., Harris, P.M. (Eds.), Unconformities and Porosity in Carbonate Strata: American Association of Petroleum Geologists, Memory, 63, pp. 239-257.

Erba, E., Channell, J.E.T., Claps, M., Jones, C., Larson, R., Opdyke, B., Premoli-Silva, L, Riva, A., Salvini, G., Torricelli, S., 1999. Integrated stratigraphy of the Cismon APTICORE (Southern Alps, Italy): a 'reference section' for the Barremian-Aptian interval at low latitudes. Journal of Foraminiferal Research 29, 371-391.

Feuillée, P., Rat, P., 1971. Structures et paléogéographies Pyrénéo-Cantabriques. In: Debyser, J., Ie Pichon, X., Montadert, L. (Eds.), Histoire Structurale du Golfe de Gascogne. Publication de I'Institute Français du Pétrole: Collection Colloque et Séminaires, Technip, Paris, 22, pp. 1-48.

Flügel, E., 2004. Microfacies of Carbonate Rocks: Analysis, Interpretation and Application. Springer-Verlag, Berlin Heidelberg. 976 pp.

Föllmi, K.B., 2008. A synchronous, middle Early Aptian age for the demise of the Helvetic Urgonian platform related to the unfolding oceanic anoxic event $1 \mathrm{a}$ ("Selli event"). Revue de Paléobiologie 27, 461-468.

Föllmi, K.B., Weissert, H., Bisping, M., Funk, H., 1994. Phosphogenesis, carbon-isotope stratigraphy and carbonate platform evolution along the Lower Cretaceous northern Tethyan margin. Geological Society of American Bulletin 106, 729-746.

Föllmi, K.B., Godet, A, Bodin, S., Linder, P., 2006. Interactions between environmental change and shallow water carbonate buildup along the northern Tethyan margin and their impact on the early Cretaceous carbon isotope record. Paleoceanography 21, PA4211.

García-Espina, R., 1997. La estructura y evolución tectonoestratigráfica del borde occidental de la Cuenca Vasco-Cantábrica (Cordillera Cantábrica, NO de España). $\mathrm{Ph}$. D. Thesis, Oviedo University, Spain.

García-Mondéjar, J., Fernández-Mendiola, P.A., 1993. Sequence stratigraphy and systems tracts of a mixed carbonate and siliciclastic platform-basin setting: the Albian of Lunada and Soba, Northern Spain. American Association of Petroleum Geologists Bulletin 77, 245-275.

García-Mondéjar, J., Agirrezabala, L.M., Aranburu, A., Fernández-Mendiola, P.A., Gómez Pérez, L, López-Horgue, M., Rosales, L, 1996. Aptian-Albian tectonic pattern of the Basque-Cantabrian Basin (northern Spain). Geological Journal 31, 13-45.

Gardner, J.A., Bosence, D., Burgess, P.M., Waltham, D., 2009. Tectono-stratigraphic models for Phanerozoic platforms. AAPG Search and Discovery Article \#90090. AAPG Annual Convention and Exhibition, Denver, Colorado, June 2009.

Gea, G.A., de, Castro, J.M. Aguado, R., Ruiz-Ortiz, P.A., Company, M., 2003. Lower Aptian carbon isotope stratigraphy from a distal carbonate shelf setting: the Cau section, Prebetic Zone SE Spain. Palaeogeography, Palaeoclimatology, Palaeoecology 200, 207-219.

Glenn, C.R., Föllmi, K.B., Riggs, S.R., Baturin, G.N., Grim, K.A., Trappe, J., Abed, A.M., GalliOlivier, C., Garrison, R.E., Ilyin, A.V., Jehl, C., Rorhlich, V., Sadaqah, R.M.Y., Schidlowski, M., Sheldon, R.E., Siegmund, H., 1994. Phosphorous and phosphorites: sedimentology and environments of formation. Eclogae Geologicae Helvetiae 87, 747-788.

Gómez-Pérez, L, Fernández-Mendiola, P.A., García-Mondéjar, J., 1998. Constructional dynamics for a Lower Cretaceous carbonate ramp (Gorbea Massif, north Iberia). In Wright, V.P., Burchette, T.P. (Eds.), Carbonate Ramps: Geological Society, Iondon, Special Publications, 149 , pp. 229-252.

Gradstein, F.M., 2004. A Geologic Time Scale 2004. Cambrige University Press.

Gradzinski, M., Tyszka, J., Uchman, A, Jach, R., 2004. Large microbial-foraminiferal oncoids from condensed Lower-Middle Jurassic deposits: a case study from the Tatra Mountains, Polan. Palaeogeography, Palaeoclimatology, Palaeoecology 213. 133-151.
Gröcke, D., Hesselbo, S.P., Jenkyns, H.C., 1999. Carbon-isotope composition of Iower Cretaceous fossil wood: ocean-atmosphere chemistry and relation to sea level change. Geology 27, 155-158.

Hallock, P., 1988. The role of nutrient availability in bioerosion: consequences to carbonate buildups. Palaeogeography, Palaeoclimatology, Palaeoecology 63, 275-291

Hallock, P., Schlager, W., 1986. Nutrient excess and the demise of coral reefs and carbonate platforms. Palaios 1, 389-398.

Hines, F.M., 1985. Sedimentation and tectonics in north-west Santander. In: Milá, M.D., Rosell, J. (Eds.), 6th European Regional Meeting, Excursion Guidebook. International Association of Sedimentologists, Lleida, Spain, pp. 371-398.

Hunt, D., Tucker, M.E., 1993. The Middle Cretaceous urgonian platform of southeastern Franœ. In: Simo, J.A.T., Scott, R.W., Masse, J.P. (Eds.), Cretaceous Carbonate Platforms: American Association of Petroleum Geologists Memory, 56, pp. 409-453.

Immenhauser, A, Kenter, J.A.M., Ganssen, G., Bahamonde, J.R., van Vliet, A, Saher, M.H. 2002. Origin and significance of isotope shifts in Penssylvanian carbonates (Asturias, NW Spain). Journal of Sedimentary Research 72, 82-94

Immenhauser, A, Della Porta, G., Kenter, J.A.M., Bahamonde, J.R., 2003. An alternative model for positives shifts in shallow marine carbonate $\delta^{13} \mathrm{C}$ and $\delta^{18} \mathrm{O}$. Sedimentology 50, 953-959.

Immenhauser, A, Hillgartner, H., van Bentum, E., 2005. Microbial foraminiferal episodes in the Early Aptian of the southern Tethyan margin: ecological significance and possible relation to Oceanic Anoxic Event 1a. Sedimentology 52, 77-99.

Immenhauser, A, Holmden, C., Patterson, W.P., 2008. Interpreting the carbon-isotope record of ancient shallow epeiric seas: lessons from the Recent. In: Pratt, B.R. Holmden, C (Eds.), Dynamics of Epeiric Seas: Geological Association of Canada, Special Paper, 48, pp. 137-174.

Jahren, A.H., Arens, N.C., Sarmiento, G., Guerrero, J., Amundson, R., 2001. Terrestrial record of methane hydrate dissociation in the Early Cretaceous. Geology 29 , $159-162$.

James, N.P., 1997. The cool-water carbonate depositional realm. In: James, N.P., Clarke, J.A.D. (Eds.), Cool-water Carbonates: SEPM Special Publication, 56, pp. 1-20.

James, N.P., Choquette, P.W., 1990. Limestones: the meteoric diagenetic environment. In: Macillreath, I.A., Morrow, D.W. (Eds.), Diagenesis. Geosciences Canada, pp. $161-194$

Jansa, L.F., 1993. Early Cretaceous carbonate platforms of the northeastern North American margin. In: Simo, J.A.T., Scott, R.W., Masse, J.P. (Eds.), Cretaceous Carbonate Platforms: American Association of Petroleum Geologists Memory, 56, pp. 111-126.

Jenkyns, H.C., 1970. Submarine volcanism and the Toarcian iron pisolites of western Sicily. Eclogae Geologicae Helvetiae 63, 741-774

Jenkyns, H.C., 1995. Carbon isotope stratigraphy and paleoceanographic significance of the Lower Cretaceous shallow-water carbonates of Resolution Guyot, Mid Pacific Mountains. In: Winterer, E.L., Sager, W.W., Firth, Sinton, J.M. (Eds.), Proceedings of the Ocean Drilling Program. Scientific Results.: Ocean Drilling Program, Collage Station, Texas, United States, 143, pp. 99-104.

Jenkyns, H.C., 2003. Evidence for rapid climate change in the Mesozoic-Palaeogene greenhouse world. Philosophical Transactions of the Royal Society A 361, 1885-1916.

Jenkyns, H.C., Wilson, P.A., 1999. Stratigraphy, paleoceanography, and evolution of Cretaceous Pacific guyots: relics from a greenhouse Earth. American Journal of Science 299, 341-392.

Kearsley, A T., 1989. Iron-rich ooids, their mineralogy and microfabrics: clues to their origin and evolution. In: Young, T.P., Taylor, W.E.G. (Eds.), Geological Society, Iondon, Special Publication, 46, pp. 141-163.

Konhauser, K.O., 1998. Diversity of bacterial iron mineralization. Earth Science Reviews 43, 91-121.

Larson, R.L., Erba, E., 1999. Onset of the Mid-Cretaceous greenhouse in the BarremianAptian: igneous events and the biological, sedimentary and geochemical response. Paleoceanography 14, 663-678.

Le Pichon, X., Sibuet, J.C, 1971. Western extension of the boundary between European and Iberian plates during the Pyrenean orogeny. Earth and Planetary Science Ietters $12,83-88$

Lehmann, Ch., Osleger, D.A., Montañez, LP., 1998. Controls on cyclostratigraphy of Iower Cretaceous carbonates and evaporites, Cupido and Coahuila platforms, northeastern Mexico. Journal of Sedimentary Research 68, 1109-1130.

Lehmann, Ch., Osleger, D.A., Montañez, LP., Sliter, W., Arnaud-Vanneau, A., Banner, J., 1999. Evolution of Cupido and Coahuila carbonate platforms, Early Cretaceous, north-eastern Mexico. Geological Society of America Bulletin 111, 1010-1029.

Luciani, V., Cobianchi, M., Jenkyns, H.C., 2001. Biotic and geochemical response to anoxic events: the Aptian pelagic succession of the Gargano promontory (southern Italy). Geological Magazine 138, 277-298.

Malod, J.A., Mauffret, A, 1990. Iberian plate motions during the Mesozoic. Tectonophysics $184,261-278$

Mamet, B., Préat, A, 2006. Iron-bacterial mediation in Phanerozoic red limestones: state of the art. Sedimentary Geology 185, 147-157

Margolis, S., Rex, R.W., 1971. Endolithic algae and micritic envelope formation in Bahamian oolites as revealed by scanning electron microscopy. Geological Society of American Bulletin 82, 843-852.

Marshall, D.J., 1988. Cathodoluminescence of Geological Materials. Unwin Hyman, Boston. $149 \mathrm{pp}$.

Marshall, D.J., 1992. Climatic and oceanographic isotopic signals from the carbonate rock record and their preservation. Geological Magazine 129, 143-160.

Martín-Chivelet, J., Berástegui, X., Rosales, L, Vilas, L., Vera, J.A., Caus, E., Gräfe, K.U., Mas, R., Puig, C., Segura, M., Robles, S., Floquet, M., Quesada, S., Ruiz-Ortiz, P.A., FrenegalMartínez, M.A., Salas, R., Arias, C., García, A., Martín-Algarra, A, Meléndez, M.N., Chacón, B., Molina, J.M., Sanz, J.L., Castro, J.M., García-Hernández, M., Carenas, B., 
García-Hidalgo, J., Gil, J., Ortega, F., 2002. Cretaceous. In: Gibbons, W., Moreno, T. (Eds.), The Geology of Spain. The Geological Society, London, pp. 255-292.

Masse, J.P., 1993. Valanginian-Early Aptian carbonate platforms from Provence southeastern France. In: Simo, J.A.T., Scott, R.W., Masse, J.P. (Eds.), Cretaceous Carbonate Platforms: American Association of Petroleum Geologists Memory, 56 pp. 363-374

Masse, J.P., El Albani, A, Erlenkeuser, H., 1999. Stratigraphie isotopique $\left(\delta^{13} \mathrm{C}\right)$ de I'Aptien inférieur de Provence (SE France); application aux corrélations plateforme/ bassin. Eclogae Geologicae Helvetiae 92, 259-263.

McCrea, J.M., 1950. On the isotopic chemistry of carbonates and a paleotemperature scale. Journal of Chemical Physics 18, 849-857.

Menegatti, A.P., Weissert, H., Brown, R.S., Tyson, R.V., Farrimond, P., Strasser, A, Caron, M., 1998. High-resolution $\delta^{13} \mathrm{C}$ stratigraphy through the Early Aptian 'Livello Selli' of the Alpine Tethys. Paleoceanography 13, 530-545.

Milkov, A.V., 2004. Global estimates of hydrate-bound gas in marine sediments: how much is really out there? Earth Sciences Reviews 66, 183-197.

Moore, C.H., 1989. Carbonate Diagenesis and Porosity. Developments in Sedimentology Elsevier, Amsterdam, $338 \mathrm{pp}$

Moreno-Bedmar, J.A., Company, M., Bover-Arnal, T., Salas, R., Delanoy, G., Martínez, R. Grauges, A, 2009. Biostratigraphic characterization by means of ammonoids of the Lower Aptian Oceanic Anoxic Event (OAE1a) in the eastern Iberian Chain (Maestrat Basin, eastern Spain). Cretaceous Research 30, 864-872.

Muchez, P., Nielsen, P., Sintubin, M., Lagrou, D., 1998. Conditions of meteoric calcite formation along a Variscan fault and their possible relation to climatic evolution during the Jurassic-Cretaceous. Sedimentology 45, 845-854

Mutti, M., 1995. Porosity development and diagenesis in the Orfento Supersequence and its bounding unconformities (upper Cretaceous, Montagna DellaMaiella, Italy) In: Budd, D.A., Saller, A.H., Harris, P.M. (Eds.), Unconformities and Porosity in Carbonate Strata: American Association of Petroleum Geologists, Memory, 63 pp. 141-158.

Nahon, D., Carozzi, A.V., Parron, C., 1980. Lateritic weathering as a mechanism for the generation of ferruginous ooids. Journal of Sedimentary Petrology 50, 1287-1298.

Najarro, M., Rosales, I., 2008a. Disoluciones e incrustaciones ferruginosas asociadas al OAE $1 \mathrm{a}$ en la plataforma carbonatada de La Florida (NO de Cantabria). Geogaceta $44,199-202$

Najarro, M., Rosales, I., 2008b. Evidencias sedimentológica, diagenética y quimioestratigráfica del Evento Anóxico Oceánico del Aptiense Inferior (OAE 1a) en la plataforma carbonatada de La Florida (NO de Cantabria). Geotemas 10, 163-166.

Najarro, M., Rosales, I., 2008c. Facies evolution, diagenesis and isotope analyses in a carbonate platform related to the Lower Cretaceous Anoxic Event 1a. SDGG 58 Abstract Volume of the 26th Regional Meeting of the International Association of Sedimentologists. Bochum, Germany, pp. 194

Najarro, M., Rosales, I., Martín-Chivelet, J., 2007. Evolución de la plataforma carbonatada de la Florida durante el rifting del Cretácico Inferior (Aptiense, NO de Cantabria). In: Bermúdez, D.D., Najarro, M., Quesada, C. (Eds.), Volumen Monográfico de la II Semana de Jóvenes Investigadores del IGME. Publicaciones del IGME, pp. 123-128.

Najarro, M., Peñalver, E., Rosales, I., Pérez-de la Fuente, R., Daviero-Gomez, V., Gomez, B., Delclòs, X., 2009. Unusual concentration of Early Albian arthropod-bearing amber in the Basque-Cantabrian Basin (El Soplao, Cantabria, Northern Spain): Palaeoenvironmental and palaeobiological implications. Geologica Acta 7 363-387.

Odin, G.S., 1988. Green Marine Clays. Developments in Sedimentology 45. Elsevier Amsterdam, $445 \mathrm{pp}$.

Odin, G.S., Matter, A, 1981. De glauconiarum origine. Sedimentology 28, 611-641.

Olivet, J.L., 1996. Ia cinématique de la plaque Ibérique. Bulletin des Centres de Recherches Exploration-Production Elf-Aquitaine 20, 131-195.

Pascal, A, 1985. Les systèmes biosédimentaires urgoniens (Aptien-Albien) sur la marge Nord Ibérique. Mémoires Géologiques de I'Úniversité de Dijon 10, 1-56s.

Perry, C.T., 1999. Biofilm-related calcification, sediment trapping and constructive micrite envelopes: a criterion for the recognition of ancient grass-bed environments? Sedimentology 46, 33-45.

Philip, J.M., Gari, J., 2005. Iate Cretaceous heterozoan carbonates: palaeoenvironmental setting, relationship with rudist carbonates (Provence, south-east France). Sedimentary Geology 175, 315-337.

Préat, A, Mamet, B., De Ridder, C., Boulvain, F., Gillan, D., 2000. Iron bacterial and fungal mats, Bajocian stratotype (Mid-Jurassic, northern Normandy, France). Sedimentary Geology 137, 107-126. at, A, El Hassani, A, Mamet, B., 2008. Iron bacteria in Devonian carbonates (Tafilat, Anti-Atlas, Marocco). Facies 54, 107-120.

Ramajo, J., Aurell, M., Cepría, J., 2002. Facies analysis of the Arroyofrío ferruginous oolitic bed in Sierra de Arcos (Jurassic, northern Iberian Chain). Journal of Iberian Geology 28, 45-64.

Ramírez del Pozo, J., 1972. Algunos datos sobre la estratigrafía y micropaleontología del Aptense y Albense al oeste de Santander. Revista Española de Micropaleontología $15,59-97$.

Rat, P., 1988. The Basque-Cantabrian basin between the Iberian and European plates some facts but still many problems. Revista de la Sociedad Geológica de España 1, 327-348.

Reolid, M., Abad, I., Martín-García, J.M., 2008. Palaeoenvironmental implications of ferruginous deposits related to a Middle-Iate Jurassic discontinuity (Prebetic Zone, Betic Cordillera, Southern Spain). Sedimentary Geology 203, 1-16.

Rosales, I., 1999. Controls on carbonate-platform evolution on active fault blocks: the Lower Cretaceous Castro Urdiales platform (Aptian-Albian, northern Spain). Journal of Sedimentary Research 69, 447-465

Rosales, I., Najarro, M., Moreno-Bedmar, J.A., Gea, G.A. de, Company, M., 2009. High resolution chemo and biostratigraphy records of the Early Aptian Oceanic Anoxic Event in Cantabria (northern Spain). Geochimica et Cosmochimica Acta, 73 (13S), A1118.

Ross, D.J., Skelton, P.W., 1993. Rudists formations of the Cretaceous: a palaeoecological, sedimentological and stratigraphical review. In: Wright, V.P. (Ed.), Sedimentology Review. Blackwell Scientific publications, pp. 73-91.

Ruiz-Ortiz, P.A., Castro, J.M., 1998. Carbonate depositional sequences in shallow to hemipelagic platform deposits; Aptian, Prebetic of Alicante (SE Spain). Bulletin de la Société Géologique de France 169, 21-33.

Sass, E., Bein, A, Almogi-Labin, A, 1991. Oxygen-isotope composition of diagenetic calcite in organic-rich rocks: Evidence for ${ }^{18} \mathrm{O}$ depletion in marine anaerobic pore water. Geology 19, 839-842.

Sælen, G., Doyle, P., Talbot, M.R., 1996. Stable-isotope analyses of belemnite rostra from the Whitby Mudstone Formation, England: surface water conditions during deposition of a marine black shale. Palaios 11, 97-117.

Schlanger, S.O., Jenkyns, H.C., 1976. Cretaceous oceanic anoxic events: causes and consequences. Geologie en Mijnbouw 55, 179-184.

Scotesse, C.R., Gahagan, L.M., Larson, R.L., 1998. Plate tectonic reconstructions of the Cretaceous and Cenozoic ocean basins. Tectonophysics 155, 27-48.

Scott, R.W., 1993. Cretaceous carbonate platform, U.S. Gulf Coast. In: Simo, J.A.T., Scott, R.W., Masse, J.P. (Eds.), Cretaceous Carbonate Platforms: American Association of Petroleum Geologists Memory, 56, pp. 97-109.

Simone, L., Carannante, G., 1988. The fate of foramol ('temperate-type') carbonate platforms. Sedimentary Geology 60, 347-354

Soto, R., Casas-Sainz, A.M., Villalain, J.J., Oliva-Urcia, B., 2007. Mesozoic extension in the Basque-Cantabrian basin (N Spain): contributions from AMS and brittle mesostructures. Tectonophysics $445,373-394$

Spicer, R.A., Corfield, R.M., 1992. A review of terrestrial and marine climates in the Cretaceous with implications for modelling the "Greenhouse Earth". Geological Magazine 129, 169-180.

Sturesson, U., Heikoop, J.M., Risk, M.J., 2000. Modern and Palaeozoic iron ooids: a similar volcanic origin. Sedimentary Geology 136, 137-146.

Vilas, L., Masse, J.P., Arias, C, 1995. Orbitolina episodes in carbonate platform evolution: the Early Aptian model from SE Spain. Palaeogeography, Palaeoclimatology Palaeoecology 119, 35-45.

Weissert, H., Erba, E, 2004. Volcanism, $\mathrm{CO} 2$ and palaeoclimate: a Late Jurassic-Early Cretaceous carbon and oxygen isotope record. Journal of the Geological Society, London, 161, 995-702.

Weissert, H., Lini, A, Föllmi, K.B., Kuhn, O., 1998. Correlation of Early Cretaceous carbon isotope stratigraphy and platform drowning events: a possible link? Palaeogeography, Palaeoclimatology, Palaeoecology 137, 189-203.

Wilmsen, M. 2000. Evolution and demise of a Mid-Cretaceous carbonate shelf: the Altamira Limestones (Cenomanian) of northern Cantabria (Spain). Sedimentary Geology 133, 195-226.

Wilmsen, M., 2005. Stratigraphy and biofacies of the Lower Aptian of Cuchía (Cantabria, northern Spain). Journal of Iberian Geology 31, 253-275

Wissler, L., Funk, H., Weissert, H., 2003. Response of Early Cretaceous carbonate platforms to changes in atmospheric carbon dioxide levels. Palaeogeography, Palaeoclimatology, Palaeoecology 200, 187-205. 